OECD Regional Development Working Papers 2016/07

Overview of Housing Policy Daniela Glocker, Interventions in Poland Marissa Plouin 


\section{OECD REGIONAL DEVELOPMENT WORKING PAPERS}

This series is designed to make available to a wider readership selected studies on regional development issues prepared for use within the OECD. Authorship is usually collective, but principal authors are named. The papers are generally available only in their original language English or French with a summary in the other if available.

OECD Working Papers should not be reported as representing the official views of the OECD or of its member countries. The opinions expressed and arguments employed are those of the author(s).

Working Papers describe preliminary results or research in progress by the author(s) and are published to stimulate discussion on a broad range of issues on which the OECD works. Comments on Working Papers are welcomed, and may be sent to either gov.contact@oecd.org or the Public Governance and Territorial Development Directorate, OECD, 2 rue André-Pascal, 75775 Paris Cedex 16, France.

Authorised for publication by Rolf Alter, Director, Public Governance and Territorial Development Directorate, OECD.

This document and any map included herein are without prejudice to the status of or sovereignty over any territory, to the delimitation of international frontiers and boundaries and to the name of any territory, city or area.

OECD Regional Development Working Papers are published on http://www.oecd.org/gov/regional/workingpapers

Applications for permission to reproduce or translate all or part of this material should be made to: OECD Publishing, rights@oecd.org or by fax 33145249930.

(C) OECD 2016 


\section{TABLE OF CONTENTS}

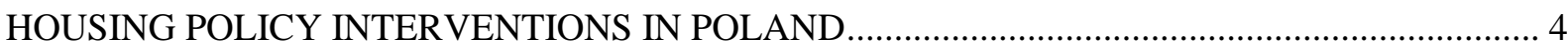

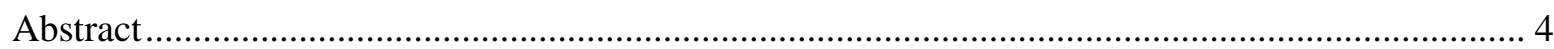

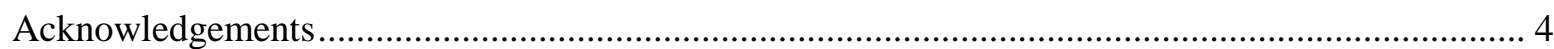

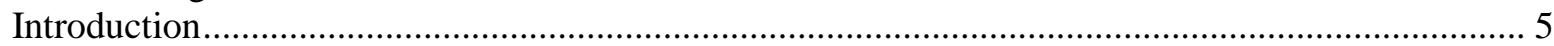

Brief overview of the evolution of the housing market in Poland ................................................ 5

Public spending and policy instruments in the housing sector ...................................................... 7

Overview of housing policy instruments and the national budget ................................................. 7

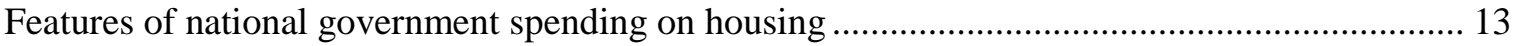

Assessing the effectiveness of public spending on housing: Key questions.................................. 13

1) What are the policy objectives of existing housing instruments, and to what extent

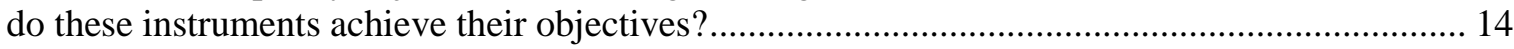

2) Who are the target beneficiaries of housing interventions, and to what extent do

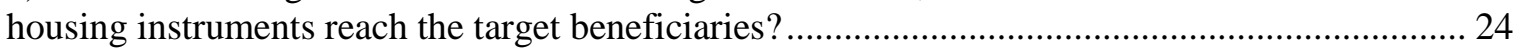

3) Have a range of policy options been considered, including those that do not imply

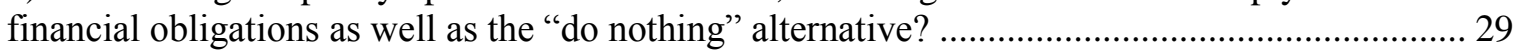

4) To what extent are monitoring and evaluation systems in place to enable an effective assessment of policy interventions? What measurable impacts (outputs, outcomes) can be

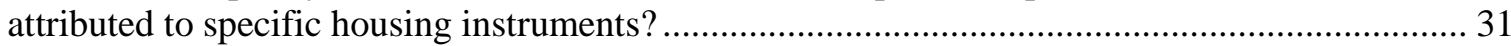

5) To what extent are housing policies coherent with other policy objectives? .............................. 41

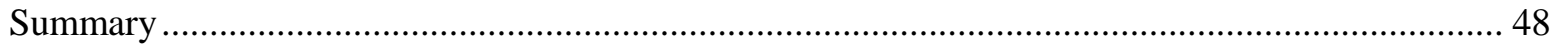

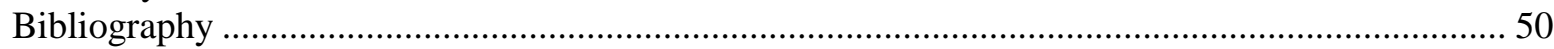

\section{Tables}

Table 1. Overview of total national government spending on housing in Poland .......................7

Table 2. Local government spending on housing and housing-related infrastructure,

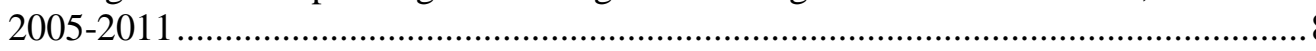

Table 3. National government expenditures on housing and housing-related infrastructure,

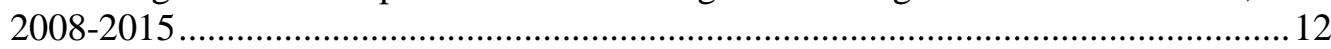

Table 4. A review of housing policy instruments in Ireland: Rationale for continuing

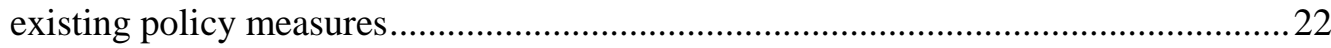

Table 5. Number of square metres financed by commercial credit affordable for a

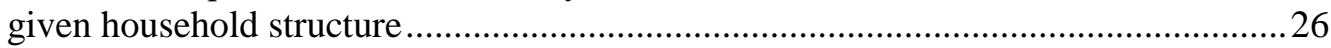

Table 6. Eligibility levels for respective housing instruments, by wage-income decile............28

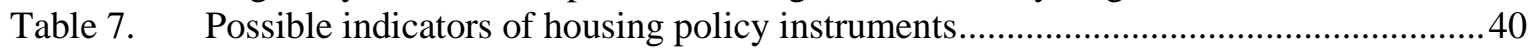

Table 8. Evaluating the potential effects of different housing programmes on policy goals ....46

\section{Figures}

Figure 1. Historic trends in housing development in Poland, 1990 to 2012 ................................ 6

Figure 2. National government budget expenditures on housing programmes.............................11

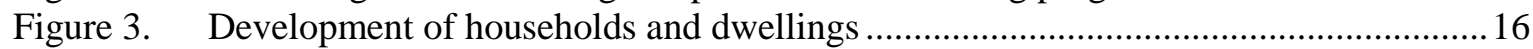

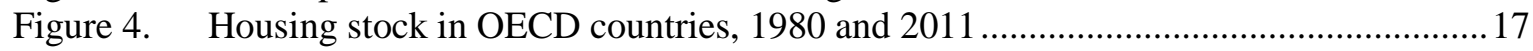

Figure 5. Overcrowding among the lowest and highest income quintiles, European countries, 2013 
Figure 6. Severe housing deprivation rate among the lowest and highest income quintiles, European countries, 2013 ....

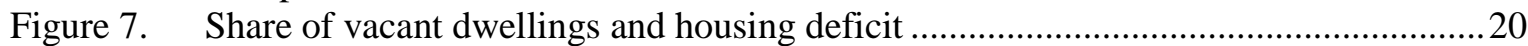

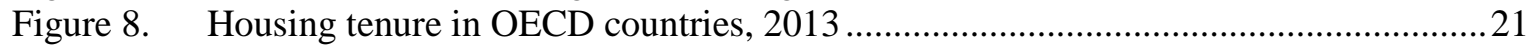

Figure 9. Household expenditure on housing in OECD countries, 2012 .................................25

Figure 10. Eligibility levels for respective housing instruments, by income decile .....................2

Figure 11. Estimated outputs of public spending on housing by end of programme .....................33

Figure 12. Residential and labour mobility / long-term unemployment ......................................42

Figure 13. Change in population density in Polish metropolitan areas...........................................4

\section{Boxes}

Box 1. Snapshot of housing programmes operated by Polish municipalities ......................... 8

Box 2. How have different OECD countries identified affordable and social housing policy objectives?

Box 3. Appraising the range of policy options: Lessons from the "Green Book" in the United Kingdom

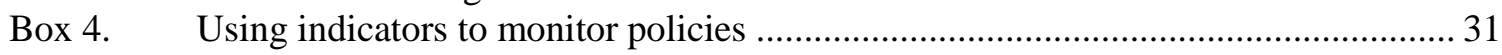

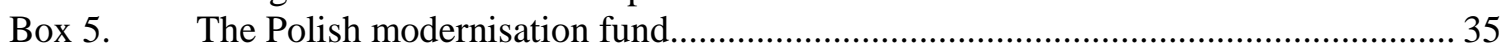

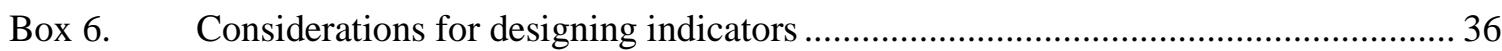

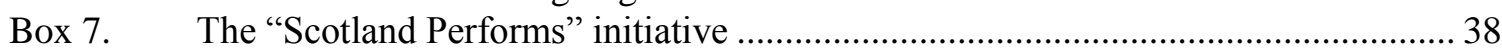

Box 8. Example of background information for an indicator ............................................. 41

Box 9. The importance of residential mobility for the labour market................................... 43

Box 10. Ireland's "Balanced Scorecard" to assist policy makers in evaluating housing expenditures ............................................................................................. 48 


\title{
OVERVIEW OF HOUSING POLICY INTERVENTIONS IN POLAND
}

\author{
By Daniela Glocker and Marissa Plouin *
}

\begin{abstract}
This paper assesses national public expenditure on housing in Poland, within the context of recent trends in the housing market. It focuses on direct expenditure on housing by the former Ministry of Infrastructure and Development, which until 2016 was the primary ministry charged with housing policy. While Poland has made considerable progress in reducing the housing deficit and improving housing quality, housing affordability and limited diversity of the housing stock remain important policy challenges. A comprehensive and conclusive evaluation of housing policy instruments in Poland is difficult, due to limited relevant data. As such, this paper outlines a series of key questions to guide policy makers in selecting housing policy instruments and in facilitating a more robust framework to measure the efficiency and effectiveness of housing policy instruments.
\end{abstract}

JEL classification code: H50, H54

Key words: governmental housing expenditure, housing instruments, housing policy, indicators, monitoring and evaluation.

\section{Acknowledgements}

This paper was conducted by the Regional Development Policy Division (RDP) at the OECD at the request of the Ministry of Finance of Poland. The analysis was undertaken by RDP, in co-operation with the Budgeting and Public Expenditures Division (BUD) at the OECD, as part of a strategic spending review of Poland. The former Ministry of Infrastructure and Development was, until 2016, the primary ministry charged with housing policy, but several other ministries and levels of governments operate housing programmes. This paper limits its assessment to direct housing expenditures by the Ministry of Infrastructure and Development. The study benefited from the input provided by the Ministry of Finance, the former Ministry of Infrastructure and Development, the National Development Bank and participants of a workshop organised jointly by the OECD and the Ministry of Finance in Warsaw in April 2015. It was written under the guidance of Rudiger Ahrend and benefited from comments by Luiz de Mello, William Tompson and Ronnie Downs. It drew on valuable inputs from Katarzyna Piętka-Kosińska of the Center for Social and Economic Research (CASE), who also provided translation support.

* OECD Regional Development Policy Division (RDP). Contact details: Daniela Glocker, Daniela.Glocker@oecd.org; and Marissa Plouin, Marissa.Plouin@oecd.org. 


\section{Introduction}

The Polish Constitution explicitly refers to housing rights and thus obliges public authorities to develop policies for the supply of adequate housing for all citizens. ${ }^{1}$ Most national housing programmes operated by the former Ministry of Infrastructure and Development ${ }^{2}$ have aimed to address the shortage of housing, which is considered to be one of the most critical housing policy challenges in Poland, particularly in urban areas. Although the official housing shortage (measured as the difference between the number of households and occupied dwellings) has decreased in recent years, the share of households living in overcrowded dwellings and the share of housing of poor quality remain large compared to other European countries, indicating a lack of quality, affordable housing alternatives. As will be discussed in this paper, the shortage of affordable housing in urban areas, combined with high levels of home ownership, could be one factor in explaining the country's low residential and labour mobility (see OECD, 2011a).

This paper assesses direct national expenditure on housing within the context of recent trends in the housing market in Poland, focusing on direct spending by the former Ministry of Infrastructure and Development. The paper will provide guidelines and highlight the requirements needed to adequately evaluate the efficiency and effectiveness of governmental spending on housing programmes. Due to the absence of appropriate data on policy objectives and programme outcomes, a comprehensive and conclusive evaluation of housing policy instruments in Poland is not feasible. Therefore, the paper proposes a series of key questions to guide policy makers in (i) planning housing policy instruments and (ii) assessing housing policy, and by extension, national government spending on housing. For each question, the policy rationale is provided, followed by an assessment of the situation in Poland and possible directions for policy makers.

The remainder of the paper is structured as follows: The first section provides a brief overview of the evolution of the housing market in Poland. It is followed by a snapshot of recent public spending and policy instruments in the housing sector in Poland, focusing on direct expenditures by the former Ministry of Infrastructure and Development and highlighting several general features of national government spending on housing. The third section aims to assist policy makers in developing tools to evaluate the efficiency and effectiveness of public expenditure on housing.

\section{Brief overview of the evolution of the housing market in Poland}

The market reforms that accompanied Poland in the post-transition period beginning in 1990 did not fully resolve the country's significant housing deficit, which had resulted from insufficient supply within a centrally planned economy (Kierzenkowski, 2008). While housing quality increased in the years following the transition, a considerable housing shortage remained. In the 2000 s, the housing market expanded rapidly, accompanied by the transformation of housing tenure. Indeed, a mass privatisation process resulted in a housing market dominated by home ownership: while roughly $44 \%$ of dwellings were privately owned at the end of the 1980s, this share had increased to $78 \%$ by 2006 (Kierzenkowski, 2008). The mass privatisation, which allowed the purchase of a home significantly below market prices,

1. "Public authorities shall pursue policies conducive to satisfying the housing needs of citizens, in particular combating homelessness, promoting the development of low-income housing and supporting activities aimed at acquisition of a home by each citizen" (Article 75(1) of the Constitution of the Republic of Poland).

2. In early 2016, the Ministry of Infrastructure and Development was split into the Ministry of Transport and the Ministry of Development. Until then, it was the primary ministry responsible for housing policy. 
contributed to two main problems. First, lower income households were able to purchase homes but were not able to cover the cost of maintaining and improving the quality of their homes, resulting in degradation of the housing stock. Second, the housing market in Poland is not flexible enough to adapt to demographic change towards single households as a result of high ownership rates.

Poland's accession to the European Union in 2004 had a significant impact on the country's housing market. In the immediate years after, banks relaxed their credit standards and foreign-currency loans became more widespread. The mortgage market, virtually non-existent in Poland in the late 1990s, began to expand - albeit slowly - as of 2000. Domestic interest rates fell contributing to increased investments in real estate, resulting in increased development in Polish cities and regions and a steep increase in real estate prices. The country experienced a considerable housing bubble, with property prices falling significantly between 2008 and 2013. The impact of dropping prices has been contained as a result of interest rate cuts and restricting on borrowing by low income households amongst other (OECD, 2014a).

The lack of affordable housing for low- and medium-income households has been aggravated by the gradual evolution of a private housing market dominated by commercial developers since the transition. The past two decades have seen a significant decline of housing produced by co-operatives and social housing developers, which were prominent under the Communist regime, countered by rapid growth in privately developed housing (Figure 1). Public policies have been instrumental in this shift, as central government policy gradually reduced incentives for the non-profit housing sector (Weclzwowicz, 2002). Currently, housing development is dominated by two market-driven sectors: individual homeowners who build homes on their own plots of land and a growing sector of commercial developers building marketrate housing. Such a shift has important implications on the housing supply for lower-income households: private developers tend to target better-off households. This is especially true for a transition economy such as Poland's, in which the price of real estate suddenly rose very steeply, and out of sync with the evolution of salaries in most employment sectors (OECD, 2014a).

Figure 1. Historic trends in housing development in Poland, 1990 to 2013

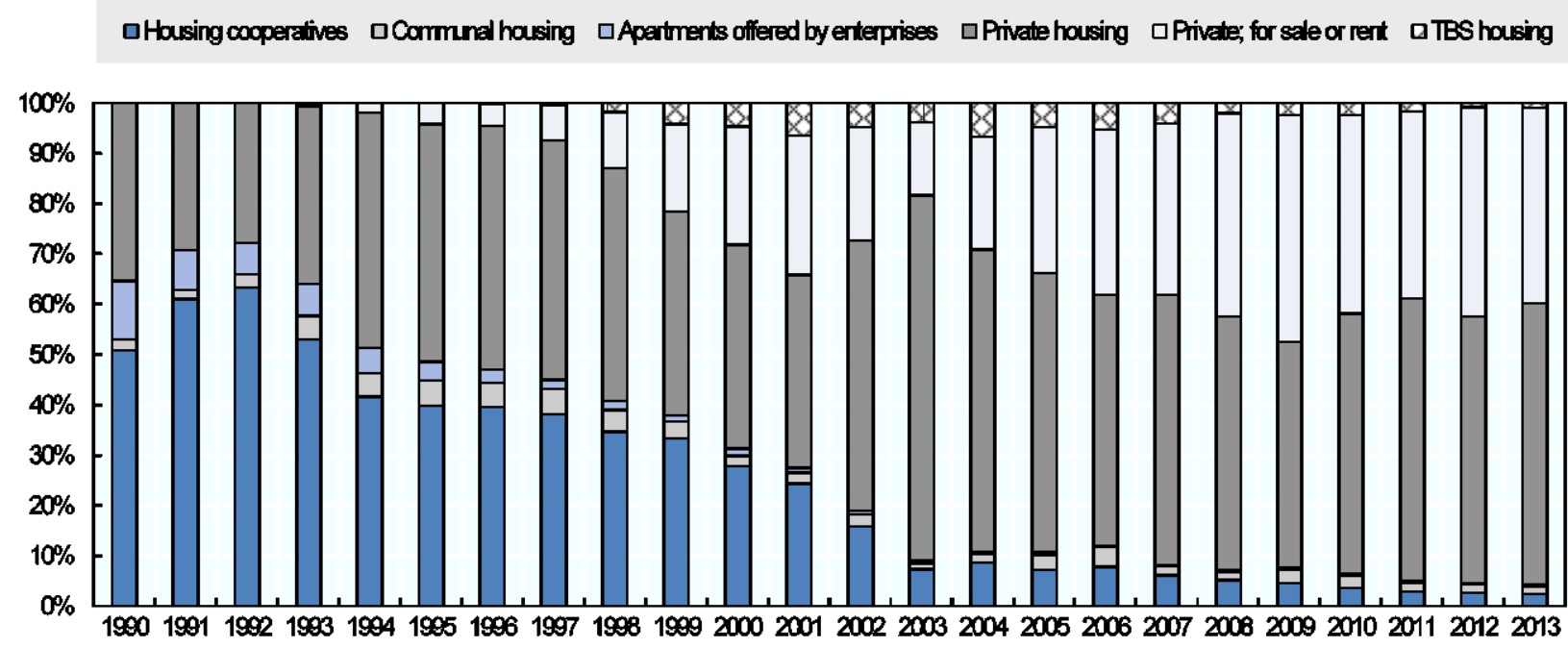

Notes: TBS housing (Towarzystwa budownictwa spolecznego) are non-profit building associations established in 1996 and inspired by the French habitation à loyer modéré (HLM) model (Kierzenkowski, 2008).

Source: Central Statistical Office of Poland (2015a), Database: Industry and Construction, Housing Construction - Dwellings completed in residential and non-residential buildings, (accessed April 2015). 


\section{Public spending and policy instruments in the housing sector}

This section first provides an overview of main housing policy instruments in the national budget. It then identifies several challenges relating to expenditures on housing.

\section{Overview of housing policy instruments and the national budget}

National and municipal (gminas) authorities are the primary public actors in housing policy in Poland, with the decentralisation of housing spending occurring at the time of the transition. Until 2016, the former Ministry of Infrastructure and Development was the primary ministry responsible for housing in Poland. Even so, municipal spending on housing is significantly higher than national government expenditure on housing (PLN 17.1 billion in 2013 [about EUR 4 billion], approximately 1.03\% of GDP, compared to PLN 1.4 billion [EUR 334 million], about $0.1 \%$ of GDP, respectively) (Box 1). Municipal expenditures on housing should thus be the subject of a separate, in-depth assessment to evaluate their effectiveness and efficiency. Moreover, some housing programmes for populations related to the military, police, and the penal system are operated by other ministries (Table 1); these expenditures are not assessed in the remainder of this paper.

\section{Table 1. Overview of total national government spending on housing in Poland}

$$
\text { 2008-2014, million PLN (current prices) }
$$

\begin{tabular}{|c|c|c|c|c|c|c|c|}
\hline & 2008 & 2009 & 2010 & 2011 & 2012 & 2013 & 2014 \\
\hline $\begin{array}{l}\text { (1) Housing in the national } \\
\text { budget }\end{array}$ & 1015 & 915 & 863 & 1368 & 1484 & 1497 & 1568 \\
\hline $\begin{array}{l}\text { (2) Housing in the budget of } \\
\text { the Ministry of National } \\
\text { Defence }\end{array}$ & 267 & 407 & 498 & 572 & 826 & 657 & n.a. \\
\hline $\begin{array}{l}\text { (3) Refund of the expenditure } \\
\text { on building materials }\end{array}$ & 1001 & 1001 & 1024 & 1065 & 1038 & 1040 & 1340 \\
\hline $\begin{array}{l}\text { (4) Housing expenditure of } \\
\text { local authorities }\end{array}$ & 14043 & 15816 & 15509 & 16300 & 16083 & 16907 & n.a. \\
\hline $\begin{array}{l}\text { (5) Forfeited tax revenues } \\
\text { (due to preferential VAT rates } \\
\text { in the social housing sector } \\
\text { and tax allowances) }\end{array}$ & n.a. & 9115 & 10040 & 11145 & 11337 & n.a. & n.a. \\
\hline Total & n.a. & 27254 & 27934 & 30450 & 30768 & n.a. & n.a. \\
\hline GDP & $\begin{array}{r}127732 \\
2\end{array}$ & $\begin{array}{r}136185 \\
0\end{array}$ & $\begin{array}{r}143735 \\
7\end{array}$ & $\begin{array}{r}155358 \\
2\end{array}$ & $\begin{array}{r}161589 \\
4\end{array}$ & $\begin{array}{r}166205 \\
2\end{array}$ & n.a. \\
\hline $\begin{array}{l}\% \text { of total housing } \\
\text { expenditure in GDP } \\
\% \text { of housing expenditure }\end{array}$ & - & $2.00 \%$ & $1.94 \%$ & $1.96 \%$ & $1.90 \%$ & - & - \\
\hline $\begin{array}{l}\text { including (1), (2) and (3) in } \\
\text { GDP }\end{array}$ & $0.18 \%$ & $0.17 \%$ & $0.17 \%$ & $0.19 \%$ & $0.21 \%$ & $0.19 \%$ & - \\
\hline $\begin{array}{l}\% \text { of housing expenditure } \\
\text { including (1) in GDP }\end{array}$ & $0.08 \%$ & $0.07 \%$ & $0.06 \%$ & $0.09 \%$ & $0.09 \%$ & $0.09 \%$ & \\
\hline
\end{tabular}

Source: Information provided by the Ministry of Infrastructure and Development. 


\section{Box 1. Snapshot of housing programmes operated by Polish municipalities}

Municipalities are responsible for the majority of spending on housing and housing-related infrastructure. This includes spending on:

- Housing benefits, which are means-tested, granted to the beneficiaries and paid directly to the administrator of the building. Until 2004, half of the housing benefits were financed from the national budget. Since then, municipalities have to fully finance housing benefits from their budget; local governments receive a higher share of income tax revenues to allocate to this programme. Further analysis should be done to determine the extent to which municipal control of housing benefits could create perverse incentives (e.g. municipal authorities attempting to limit the level of low-income households in the community).

- $\quad$ Rental units in municipally-owned dwellings, which are managed by municipal governments and offer below-market rent (although there is no upper limit in municipal dwellings, in practice municipalities charge between $1-3 \%$ of replacement costs). Eligibility of the tenant is only checked at the time of application. Even so, rent for these units is often set below $4 \%$ of the replacement value, making it hard for municipalities to afford renovations and improvements of the housing stock.

- Emergency housing, which accommodates the very poor and homeless persons (national funds are available to assist with these programmes). Rather than develop new emergency housing, many municipalities in possession of a deteriorated (municipally-owned) housing stock often use rental income from these dwellings to construct new homes for low-income households, using the deteriorated housing stock for emergency homes. As discussed later in this paper, rental income does not always cover maintenance costs.

- $\quad$ Technical infrastructure and communal services related to housing. Spending in this category covers water and sewage systems, waste collection, greenery, street lighting and other public services.

The structure of local government spending on housing and housing-related infrastructure from 2005 to 2013 is detailed in Table 2. Of the total, $60 \%$ was spent on housing-related infrastructure investments and environmental protection, $35 \%$ on maintenance and administration of the municipal housing stock, and $6 \%$ on individual means-tested housing allowances.

Table 2. Local government spending on housing and housing-related infrastructure, 2005-2013

PLN million, current prices

\begin{tabular}{|l|r|r|r|r|r|r|r|r|r|}
\hline Instrument & $\mathbf{2 0 0 5}$ & $\mathbf{2 0 0 6}$ & $\mathbf{2 0 0 7}$ & $\mathbf{2 0 0 8}$ & $\mathbf{2 0 0 9}$ & $\mathbf{2 0 1 0}$ & $\mathbf{2 0 1 1}$ & $\mathbf{2 0 1 2}$ & $\mathbf{2 0 1 3}$ \\
\hline Housing allowances & 1240 & 1168 & 1047 & 834 & 807 & 866 & 884 & 930 & 982 \\
\hline $\begin{array}{l}\text { Administration and } \\
\text { maintenance of municipal } \\
\text { housing stock } \\
\text { (Gospodarka } \\
\text { mieszkaniowa) }\end{array}$ & 3697 & 4048 & 4290 & 5384 & 5723 & 5744 & 6099 & 6290 & 5936 \\
\hline $\begin{array}{l}\text { Housing-related } \\
\text { infrastructure and } \\
\text { environmental protection }\end{array}$ & 5715 & 6510 & 6896 & 7840 & 9286 & 9899 & 9317 & 8863 & 10169 \\
\hline \begin{tabular}{l} 
Total \\
\hline $\begin{array}{l}\text { Share of total municipal } \\
\text { spending }\end{array}$
\end{tabular} & 10652 & 11726 & 12233 & 14058 & 15816 & 16509 & 16300 & 16083 & 17087 \\
\hline
\end{tabular}

Source: Central Statistical Office (2015b), Database: Public Finance - Expenditure of Gminas and Cities with Powiat Status Budgets. 


\section{National government spending on housing: main programmes and policy instruments}

Public spending on housing in Poland amounted to about $1.9 \%$ of GDP in 2012, of which about $0.1 \%$ of GDP resulted from direct national government budget expenditures on housing instruments. Housingrelated expenditures consist of both active housing programmes, as well as liabilities from inactive programmes and pre-transition obligations, which still require considerable national resources (Figure 2 and Table 3). Further, a partial VAT refund and a reduced VAT rate for construction materials are also a significant means of public intervention in the housing market with an indirect effect on the national government budget.

The three primary active programmes administered by the former Ministry of Infrastructure and Development include:

- Housing for the Young (Mieszkanie dla Młodych) is a co-financing mechanism introduced in 2014 and amended by the government in 2015, with applications to be accepted until 2018. Housing for the Young targets first-time home-buyers aged 35 and under who are applying for a mortgage in the primary market. For families with two children or fewer, persons are eligible if they have not previously owned a dwelling. Additional eligibility criteria include a maximum dwelling size and maximum price per square meter $\left(75 \mathrm{~m}^{2}\right.$ for a flat, $100 \mathrm{~m}^{2}$ for a house, plus an additional $10 \mathrm{~m}^{2}$ for families with at least three children; the price of the square meter cannot exceed local limits, which is based on the average housing construction cost plus 10\%). The programme is considered "pro-family" in the sense that applicants with at least three children receive priority in the form of less strict eligibility criteria, as well as additional support for mortgage repayment if a third child is born within five years of the date of home ownership title.

- The modernisation and renovation support programme consists of two parts. The modernisation bonus has been in operation since 1999, providing subsidies to reduce the energy consumption of residential buildings. In 2008, the programme was supplemented with an opportunity to obtain a renovation bonus for multi-family buildings developed before 1961 . The programme aims to increase the quality of the existing housing stock and generate energy savings (see Box 5).

- Financial support for the emergency housing programme, introduced in 2007, provides 30-50\% of co-financing to local authorities for the purchase, construction or refurbishment of very lowincome rental housing. In the case of construction or refurbishment of premises that will serve as night shelters or homes for the homeless, local authorities as well as NGOs are eligible for support. Overall, this programme receives a relatively small share of the national housing expenditure (about $5 \%$ in 2015).

There are also inactive programmes (i.e. programmes that are not open for application anymore) that still require considerable national resources:

- The Family's Own Home programme (Rodzina na Swoim), the predecessor of Housing for the Young, accepted applications between 2007 and 2012. This programme offered a temporary mortgage interest subsidy (lasting for eight years) to married couples and single parents for the purchase of a home. Eligibility criteria were adjusted between 2007 and 2012, but included maximum useable floor space and maximum price per square meter, adjusted regionally. Although applications for this programme ended in 2012, resources from the national budget will have to be allocated to fulfil the open liabilities of the programme through 2021. 
- Additional pre-transition liabilities stem from support for loan repayment and guarantee bonus, which aim to mitigate the negative impacts of the transition for people who repay housing loans taken up prior to 1992 and people saving via the so-called housing saving booklets. These subsidies were introduced following high inflation in 1990. The support to loan repayments are subsidies enabling the repayment of interest on mortgages taken up by co-operatives up to 1992. The guarantee bonus, on the other hand, ensures that individuals who have used housing saving booklets do not encounter losses resulting from inflation. The resources allocated to these pretransition liabilities in 2015 amounted to about $26 \%$ of direct national expenditure on housing by the Ministry of Infrastructure and Development.

In total, almost $50 \%$ of direct national expenditure on housing by the Ministry of Infrastructure and Development was allocated to inactive programmes in 2015.

Moreover, two housing instruments, which are based on VAT refunds and reductions, also affect the national budget:

- The first is a refund of part of the VAT paid by natural persons related to construction materials for the construction of a house. The system was introduced after Poland joined the European Union and VAT rates for construction materials increased dramatically, from $7 \%$ to $22 \%$. To compensate for the increase, the national budget refunds the difference between the baseline and the reduced rate paid in connection with purchase of construction materials for renovation or construction of dwellings.

However, by the end of 2013, this programme was terminated, as it has dominated housing budget expenditures and was geared towards higher-income people. Since 2014, VAT compensation is limited to persons who are constructing their first home and who fulfil the criteria of the Housing for the Young programme. As the refund to beneficiaries is paid in the year of completion of the investment, there have not yet been any statistics (beneficiaries) of this programme.

- The second is a reduced VAT rate (from $23 \%$ to $8 \%$ ) for residential housing construction, renovation and maintenance. Until the end of 2010, there were no floor space limits; after 2010 the reduced tax rate concerns services related to the construction or renovation of single-family residential buildings with the usable floor space of up to $300 \mathrm{~m}^{2}$ and residential apartments with the usable floor space of up to $150 \mathrm{~m}^{2}$. In 2012, the forfeited revenue amounted to PLN 11 billion [EUR 2.6 billion], based on estimates in Annual Reports from the Ministry of Finance (Ministry of Finance, 2014). 
Figure 2. National government budget expenditures on housing programmes

\section{$2001-2015^{\star *}$}

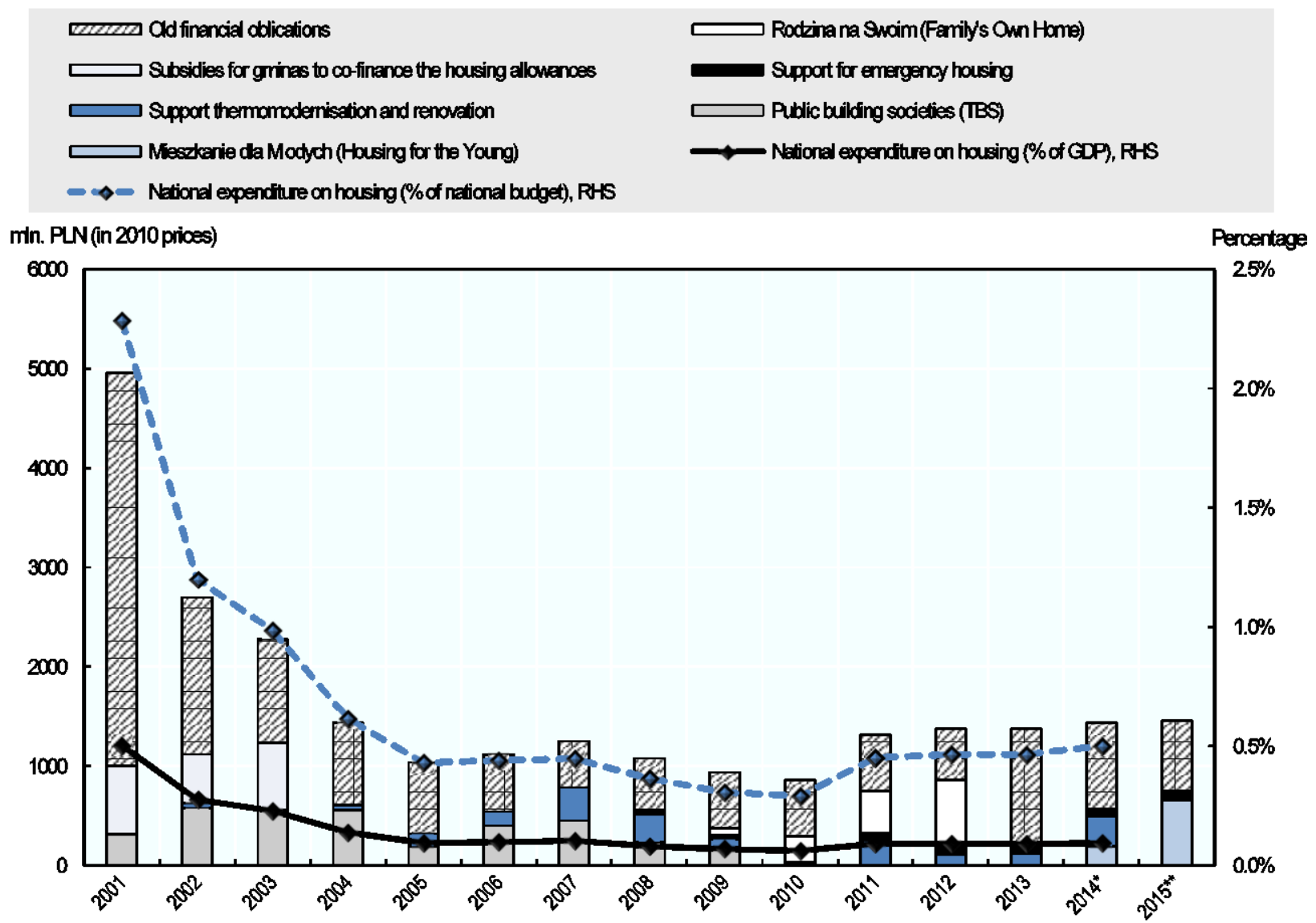

Note: In 2010 prices, deflated with the Harmonised Consumer Price Index (OECD, 2015a). *Data for 2014 is preliminary, ${ }^{* *}$ Data for 2015 is according to the draft budget act. Old liabilities include support for repayment of pre-transition co-operative mortgages, pretransition guarantee premiums and since 2013 liabilities stemming from the Family's Own Home programme.

Source: Ministry of Finance (2015), Background Report prepared by the Ministry of Finance on the basis of the data of National Statistical Office and the Ministry of Finance; document is not publicly available. 
Table 3. National government expenditures on housing and housing-related infrastructure, 2008-2015

PLN million, current prices

\begin{tabular}{|c|c|c|c|c|c|c|c|c|c|c|}
\hline Instrument & $\begin{array}{l}\text { Is the programme active, } \\
\text { i.e. is it still possible to } \\
\text { apply for it? }\end{array}$ & 2008 & 2009 & 2010 & 2011 & 2012 & 2013 & 2014 & 2015 & $\begin{array}{l}\text { Share of total } \\
\text { national govt } \\
\text { spending on } \\
\text { housing } 2015 \\
\end{array}$ \\
\hline \multicolumn{11}{|l|}{ Support for home ownership } \\
\hline $\begin{array}{l}\text { Housing for the Young } \\
\text { (Mieszkanie dla Młodych) }\end{array}$ & $\begin{array}{l}\text { Yes: applications accepted } \\
\text { 2014-2018 }\end{array}$ & & & & & & & 208 & 715 & $45 \%$ \\
\hline $\begin{array}{l}\text { Family's Own Home } \\
\text { (Rodzina na Swoim) }\end{array}$ & $\begin{array}{l}\text { No: applications accepted } \\
2007-2012 \text {, but considerable } \\
\text { budget implications through } \\
2021\end{array}$ & & 60 & 255 & 439 & 689 & 800 & 595 & 360 & $23 \%$ \\
\hline \multicolumn{11}{|l|}{ Support for rental housing } \\
\hline $\begin{array}{l}\text { Public building societies } \\
\text { (TBS): rental housing for } \\
\text { low/moderate (below } \\
\text { median) income }\end{array}$ & $\begin{array}{l}\text { No: in operation since 1995; } \\
\text { programme was financed by } \\
\text { national budget through } \\
2009^{0 a}\end{array}$ & 220 & 150 & & & & & & & \\
\hline $\begin{array}{l}\text { Social rental housing for } \\
\text { very low income } \\
\text { households ("Emergency } \\
\text { Housing") }\end{array}$ & Yes: since 2007 & 25 & 45 & 40 & 80 & 120 & 90 & 80 & 80 & $5 \%$ \\
\hline \multicolumn{11}{|c|}{ Support for maintaining and improving the existing housing stock } \\
\hline $\begin{array}{l}\text { Support for modernisation } \\
\text { and renovation }\end{array}$ & Yes: since 1999 & 270 & 109 & 0 & 260 & 120 & 133 & 330 & 20 & $1 \%$ \\
\hline \multicolumn{11}{|l|}{ Pre-transition liabilities } \\
\hline Guarantee premiums & No: since $1990^{\circ}$ & 347 & 403 & 429 & 445 & 435 & 398 & 303 & 350 & $22 \%$ \\
\hline $\begin{array}{l}\text { Support for repayment of } \\
\text { pre-transition housing co- } \\
\text { operative mortgages }\end{array}$ & No: since $1996^{6}$ & 152 & 148 & 138 & 143 & 119 & 75 & 52 & 60 & $4 \%$ \\
\hline \multicolumn{2}{|c|}{ Total national government spending on housing } & 1,014 & 915 & 862 & 1,367 & 1,483 & 1,496 & 1,568 & \begin{tabular}{|l|}
1,585 \\
\end{tabular} & $100 \%$ \\
\hline
\end{tabular}

Notes: $\quad$ a: The TBS social housing programme was discontinued in 2009. A replacement programme was in advanced stages in mid-2015.

b: The pre-transition liabilities are programmes that still have budget implications resulting from pre-transition programmes which aimed to mitigate the negative impacts of the transition for people who repay housing loans taken up prior to 1992 and people saving via the so-called housing saving booklets. 


\section{Features of national government spending on housing}

Several features with respect to public spending on housing at national level are worth noting. Some of these may contribute to reduce the overall effectiveness of housing policy instruments (e.g. a large share of budget spent on programmes that are no longer active) or, in some cases, make it harder to measure policy effectiveness (e.g. frequent changes to housing instruments and eligibility criteria).

- $\quad$ Limited flexibility within the housing budget for innovating housing policy. Nearly half of direct expenditures on housing by the Ministry of Infrastructure and Development are allocated to inactive programmes and pre-transition liabilities. In 2015, nearly half $(49 \%)$ of all national government expenditure on housing by the Ministry is projected to be spent on programmes that are no longer active (e.g. Family's Own Home and pre-transition liabilities). In 2014, this share was even larger amounting to $60 \%$ (Table 3 ). These obligations take priority within the budget and leave little fiscal space for housing policy innovations that might offer more flexible or forward-looking instruments. Moreover, the remaining fiscal space could progressively shrink should the overall budget allocations to housing decrease, leaving even more limited scope to develop strategic housing instruments.

- Frequent changes in housing instruments, programme rules and eligibility requirements. Housing policy instruments tend to change frequently, as do the eligibility criteria (e.g. Family's Own Home). Housing programmes are often discontinued as a result of general fiscal tightening, rather than as a result of a clearly articulated policy failure (Herbst, 2012). In the case of the Housing for the Young programme changes were already considered in its second year, for instance, the progressively increase support for households based on the number of children. Such changes to policy criteria could lead to a lack of clarity for those in need of housing assistance. Additionally, they complicate an in-depth evaluation of different housing policies. One exception is the former social rental housing programme (TBS), which maintained relatively consistent rules and eligibility criteria throughout its course (1996-2008) (Brzeski et al., 2009).

- Most spending for programmes has long-term implications for the housing budget. More than 90\% of direct national government expenditures on housing are allocated to programmes or liabilities that will continue to have considerable budgetary implications over the long term; just $6 \%$ of spending is allocated to one-time assistance (e.g. support for maintenance and renovation programmes; transfers to municipal governments to increase the emergency housing supply). Further, some of the largest housing expenditures currently in the budget project most spending obligations to occur in later years of the programme (e.g. $70 \%$ of the spending for the Family's Own Home programme will be spent in the final years of the programme, 2016 to 2018). While such a strategy may relieve pressure on the current budget, it will impose more significant budgetary stress in later years.

- Housing programmes are shaped by overall budgetary allocations, rather than a long-term housing strategy. The fiscal approach of the Ministry of Finance tends to dominate the process of setting housing goals and shaping housing programmes. Such an approach makes it difficult to develop long-term, strategic housing policy based on a comprehensive analysis of concrete outputs of past programmes and new policy objectives based on the needs of the population.

\section{Assessing the effectiveness of public spending on housing: Key questions}

A comprehensive, conclusive evaluation of housing policy instruments in Poland is difficult. First, as mentioned above, policy instruments have been unstable, changing from year to year. Moreover, even throughout the course of a given programme (such as Family's Own Home, Rodzina na Swoim), multiple 
changes to the rules and eligibility requirements were made that altered the targeted beneficiaries. Not only do these changes in eligibility criteria make it difficult to evaluate the ultimate outcomes of a given policy, they may also indicate an underlying difficulty in formulating and adhering to explicit objectives and/or a clearly defined target group to benefit from the instrument. Second, systematic monitoring and evaluation schemes do not appear to be in place for most programmes, making it impossible to establish causation or even correlation with respect to current or past housing policies. An exception is the TBS programme, which was evaluated by inter alia the European Investment Bank (EIB) (2011) and Brzeski et al. (2009) and the modernisation programme (see Box 5). Third, most indicators that have been collected have been focused on outputs, rather than outcomes (a distinction that will be discussed in greater detail below); outputs are not an optimal measure of policy success.

In the absence of comprehensive data on programme objectives and outcomes, this section proposes a series of key questions that can guide policy makers in (i) planning housing policy instruments and (ii) monitoring both the efficiency and effectiveness of housing policy instruments, and by extension, national government spending on housing. These two dimensions of performance are related but distinct: effectiveness is concerned with performance in respect of the objectives set, without regard to cost. Effectiveness reforms may be cost-increasing, cost-neutral or cost-decreasing. Efficiency refers to the relationship between cost and outcome: efficiency reforms aim at better outcomes for any given level of expenditure. The key questions are as follows:

1. What are the policy objectives of existing housing instruments, and to what extent do these instruments achieve policy objectives?

2. Who are the target beneficiaries of housing interventions, and to what extent do housing instruments reach the target beneficiaries?

3. Have a range of policy options been considered, including those that do not imply financial obligations and a "do nothing" alternative?

4. To what extent are monitoring and evaluation systems in place to enable an effective assessment of policy interventions? What measurable impacts (outcomes, outputs) can be attributed to specific housing instruments?

5. To what extent are housing policies coherent with other policy objectives, and vice-versa?

In this section, each question begins with a short description of the rationale, followed by an assessment of the situation in Poland, and concludes with potential, practically-minded directions for policy assessment in Poland.

\section{1) What are the policy objectives of existing housing instruments, and to what extent do these instruments achieve their objectives?}

\section{Rationale}

Each housing policy initiative should have a clear objective or set of objectives. Even if this seems obvious, it is not always clear what policies are intended to achieve and much less so if they ultimately succeed in achieving their objectives. Clear policy objectives are a prerequisite for developing outcome indicators (discussed further below). Without them, it is unclear what indicators should measure. The more explicit the objectives formulated, the easier is the development of suitable indicators (see e.g. Schumann, 2016). 


\section{Assessment of the situation in Poland}

In response to the 2014 OECD Questionnaire on Affordable and Social Housing (see Salvi del Pero et al., 2016), Poland identified five housing policy objectives: (i) reduce the housing deficit by increasing the number of new dwellings; (ii) support home ownership for families with young children; (iii) facilitate access to affordable dwellings for low-income households; (iv) regenerate the old housing stock, especially in terms of energy efficiency; and (v) clear past obligations rooting from the former Socialist era.

Poland has made some progress towards two of its central housing objectives: reducing the housing deficit $^{3}$ and improving housing quality through the regeneration of the existing housing stock. A large and persistent housing deficit of about 1.25 million dwellings in 1988 (Figure 3) was partly inherited from the Communist regime. By 2002, the shortage had increased by $26 \%$ as a result of insufficient attention to housing policy in the years after the transition and housing construction that did not match demographic trends towards an increase in small and single-occupancy households. Between 2002 and 2011, however, policy efforts to boost housing construction led to a slight reduction in the national housing deficit. ${ }^{4}$ This reduction is mainly driven by development in urban areas where the housing deficit declined by nearly 17\% between 1988 and 2011. In contrast, the deficit in rural areas has remained relatively stable (Ministry of Transport Construction and Maritime Economy, 2013). The primary means of reducing the housing deficit has been to stimulate the construction of new homes through various national programmes (the VAT refunds and reductions, as well as programmes like Family's Own Home and Housing for the Young), as well as municipal initiatives (via the construction of social housing and emergency housing).

3. The Ministry of Infrastructure and Development defines the housing shortage as difference between the number of households and the number of occupied dwellings. This definition has some shortcomings: namely, vacant dwellings (which account for up to $13 \%$ in some areas, e.g. the Warsaw area) are not taken into account. If vacant dwellings were included in the calculation of the housing shortage, the housing shortage would not appear as severe; thus, more effort could be made to understand the causes for the high number of housing vacancies. In addition, there is little information about who is affected most by the housing deficit (i.e. is the problem that there are not enough houses built, or not enough affordable houses available?).

4. The Ministry of Transport, Construction and Maritime Economy estimated the number of vacant dwellings at 691000 in 2013; this paper cites the 2011 estimate from the Census in order to maintain methodological consistency over time. 
Figure 3. Development of households and dwellings

1988, 2002 and 2011
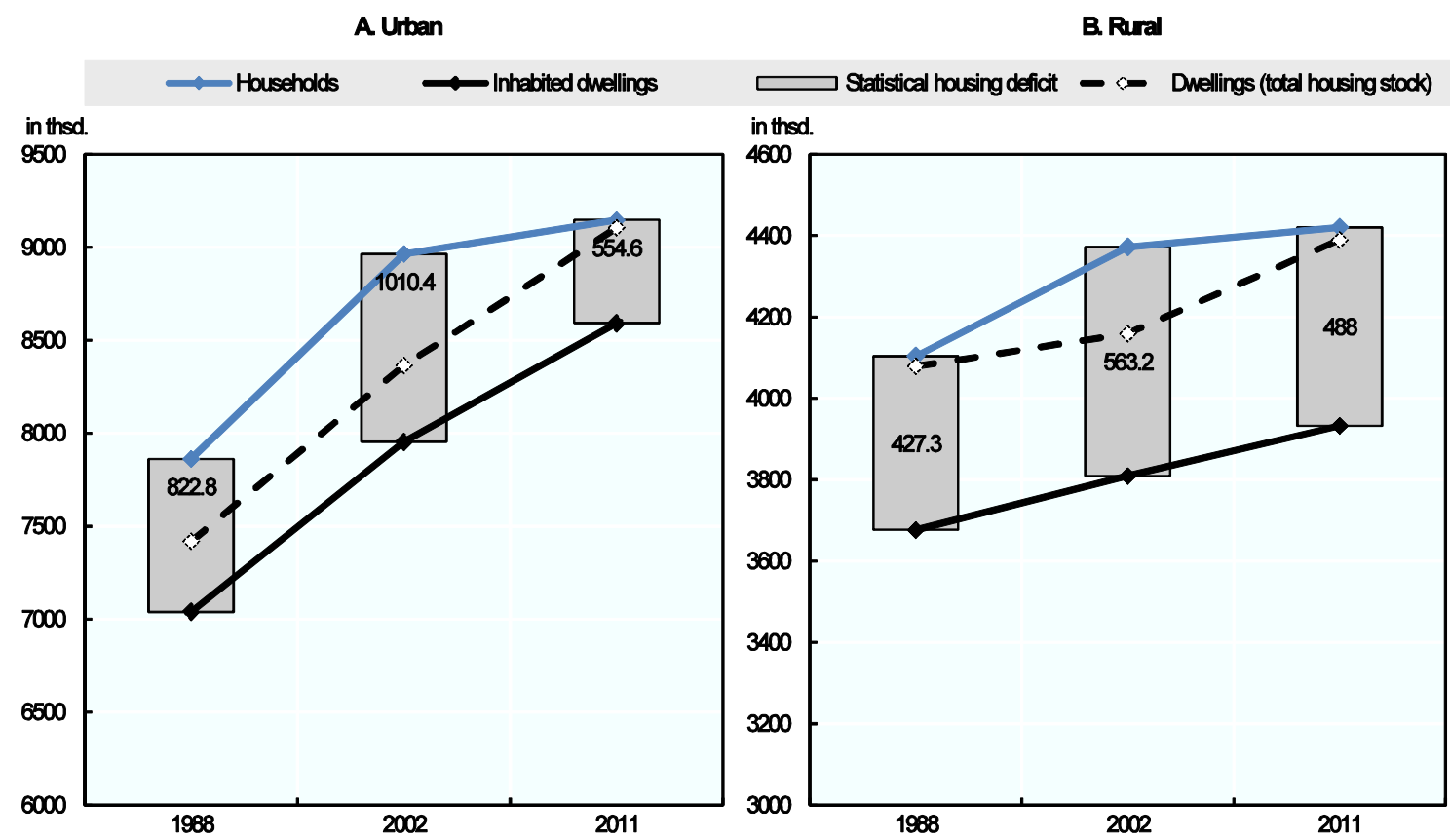

Note: The statistical housing deficit is the difference between households and inhabited dwellings.

Source: Ministry of Transport, Construction and Maritime Economy (2013), "The Housing Situation in Poland", based on Polish census data (1988, 2002 and 2011, with estimates for 2013).

Public policies were likely a factor in reducing the housing deficit, although it is not clear to what extent specific policies and programmes have contributed to its reduction. Moreover, there is evidence that some initiatives may have had a smaller effect than anticipated. Radzimski (2014) finds that subsidised loans did not stimulate as much new residential construction as desired; in fact, the number of housing permits decreased during the period of policy implementation: "only $26 \%$ of all subsidised loans were provided to households buying new dwellings" and "about $18 \%$ of subsidised loans were utilised for the construction of single family homes by private persons" (Radzimski, 2014: 479). It is conceivable that the policy interventions related to the VAT (reduced rate or refunds) had some effect on housing production, but it is not known to what extent.

Poland has not made as much headway in increasing the housing stock in recent decades as have other OECD countries. Across the OECD, Poland recorded the fourth-lowest number of dwellings per 1000 inhabitants in 1980 (Figure 4). By 2011, Poland had increased its share of dwellings per 1000 residents by about $24 \%$, and compared to OECD countries in Eastern Europe was outperformed by Slovakia (58\%) and Hungary (33\%). As will be discussed later in this paper, growth of the housing stock is one possible measure of successful housing policy; however, it is not necessarily an indication of whether the new housing successfully meets household demand (i.e. in terms of whether the new housing is affordable to households, and/or whether it is of a size and type and in a location that meets demand). 
Figure 4. Housing stock in OECD countries, 1980 and 2011

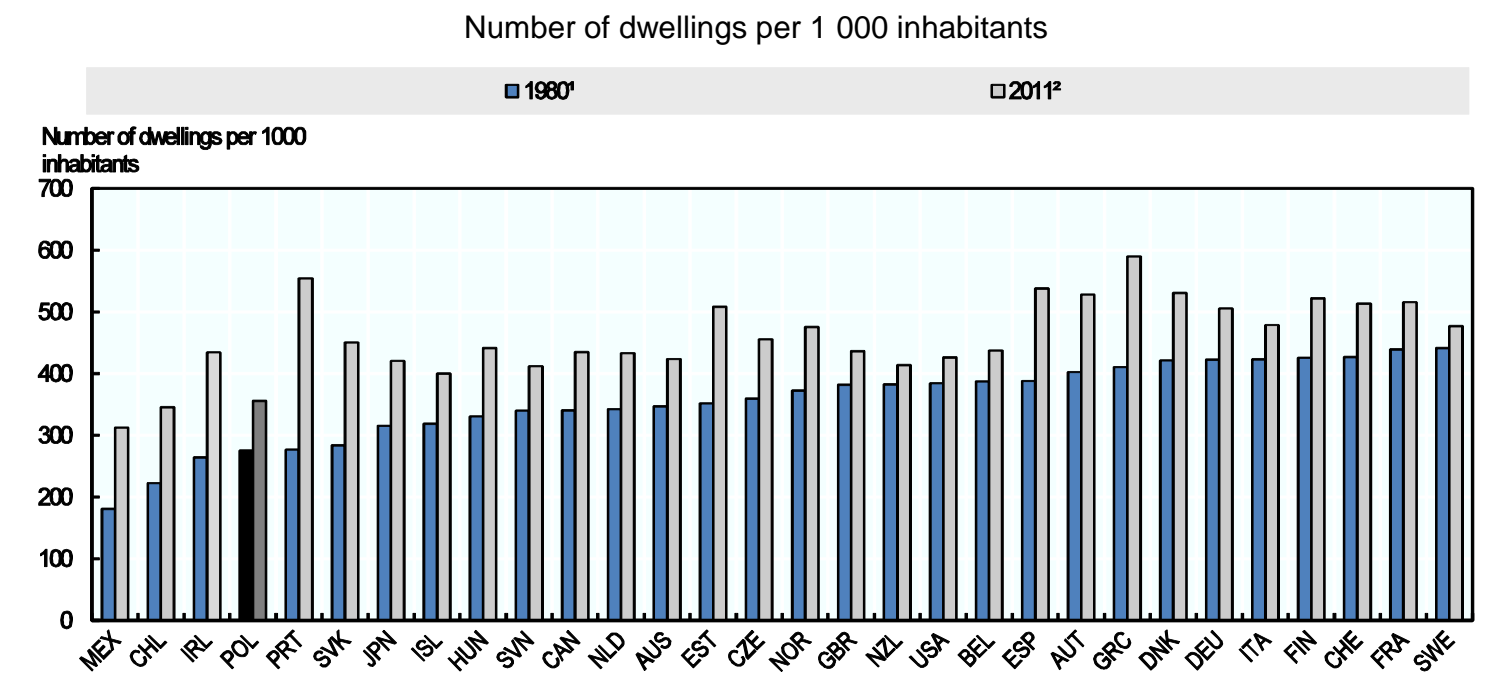

Note: 1.1981 for Australia; 1982 for France; 1986 for Germany; 1988 for Finland; 1989 for Portugal and 1990 for Italy. 2.2008 for Japan; 2010 for Finland, Germany, Mexico, Switzerland and the United States; 2012 for Chile; 2013 for France, New Zealand and Sweden.

Sources: Andrews, D., A. Caldera Sánchez and Å. Johansson (2011), "Housing markets and structural policies in OECD countries", OECD Economics Department Working Papers, No. 836, OECD Publishing, Paris, http://dx.doi.org/10.1787/5kgk8t2k9vf3-en; INEGI (1980), Censo General de Población y Vivienda 1980; INEGI (2010), Censo General de Población y Vivienda 2010. For 2010 data from OECD countries: Chile: OECD (2013a), OECD Urban Policy Reviews: Chile 2013, OECD Publishing, Paris, http://dx.doi.org/10.1787/9789264191808-en; Central Statistics Office Ireland (2011), "Census 2011"; Central Statistical Office of Poland (2011), Census Results; Instituto Nacional de Estatística (2011), XV Recenseamento geral da população. V Recenseamento geral da habitação; United Nations National Statistics Office (2014), "Dwellings per 1000 people"; available at: www.helgilibrary.com/indicators/index/dwellings-per-1000-people (for Italy, Japan, Slovak Republic); Hungarian Central Statistical Office (2011), Population Census 2011; Statistical Office of the Republic of Slovenia (2013), Population Census 2011; Statistics Canada (2011), Census; Statistics Netherlands (2011), "Changes in the dwelling stock: 1995-2011"; Australian Bureau of Statistics (2011), Census; Statistics Estonia (2012), Population and Housing Census in 2011; Czech Statistical Office (2011), Census Results; Statistics Norway (2011), StatBank Norway; Office for National Statistics (2011), 2011 Census; Statistics New Zealand (2013), 2013 Census; United States Census Bureau (2010), Census of Population and Housing; Statistics Belgium (2011), Population and Housing Census; Instituto Nacional de Estadística (2011), Censos de Población y Viviendas 2011; Statistics Austria (2011), Census 2011; Hellenic Statistical Authority (2011), 2011 Population and Housing Census; Statistics Denmark (2011), StatBank Denmark; Federal Statistics Office (Germany) (2010), Microcensus 2010 - Construction and Housing; Official Statistics of Finland (2010), Dwellings and Housing Conditions; Statistique Suisse (2010), Stat-Tab; INSEE (2013), "Logement", available at: www.insee.fr/fr/themes/document.asp?reg_id=0\&id=4222; Statistics Sweden (2013), Statistical Database.

In terms of improving housing quality, progress has been slow but has nonetheless steadily increased since the 1990s (see Frackowiak, 2008). As Radzimski (2014) points out, most of the housing stock now meets minimum quality standards in terms of equipment, but many dwellings are not in line with modern needs. The share of dwellings identified in the Polish census as "substandard" decreased from $33 \%$ of the housing stock in 1998 to $11 \%$ in 2011 (Ministry of Transport Construction and Maritime Economy, 2013). Moreover, the share of dwellings with basic infrastructure (relating to water, sewage and central heating) has also improved in the past three decades, with the largest gains in rural areas. By 2011, in both urban and rural areas, most housing was equipped with piped water (97\%), bathrooms (92\%) and central heating (82\%) (Central Statistical Office Poland, 2015c).

Overcrowding remains a significant challenge. In 2013, 45\% of the Polish population experienced overcrowding (Eurostat, 2015a). Among European OECD countries, only Hungary (46\%) and Slovakia (40\%) registered similar levels. Lower- and medium-income households are more likely to live in overcrowded housing due to a lack of affordable alternatives: in 2013, 61\% of Polish households in the lowest income quintile experienced overcrowding, compared to $30 \%$ of households in the highest income quintile (Figure 5). Even so, Poland registers the second-highest share of the population experiencing overcrowding for both the highest and lowest-income households across European OECD countries. The 
overcrowding rate in Poland has nevertheless declined in recent decades. The decline is partly a result of the increasing size of housing units: the average number of rooms per dwelling increased by $13 \%$ between 1988 and 2011, while the average living space grew by 23\%. These changes were more pronounced in rural areas, compared to urban areas (Ministry of Transport Construction and Maritime Economy, 2013). Over the same period, the average number of persons per dwelling dropped by $12 \%$ overall, while the average size of living space per person increased by $39 \%$.

Figure 5. Overcrowding among the lowest and highest income quintiles, European countries, 2013

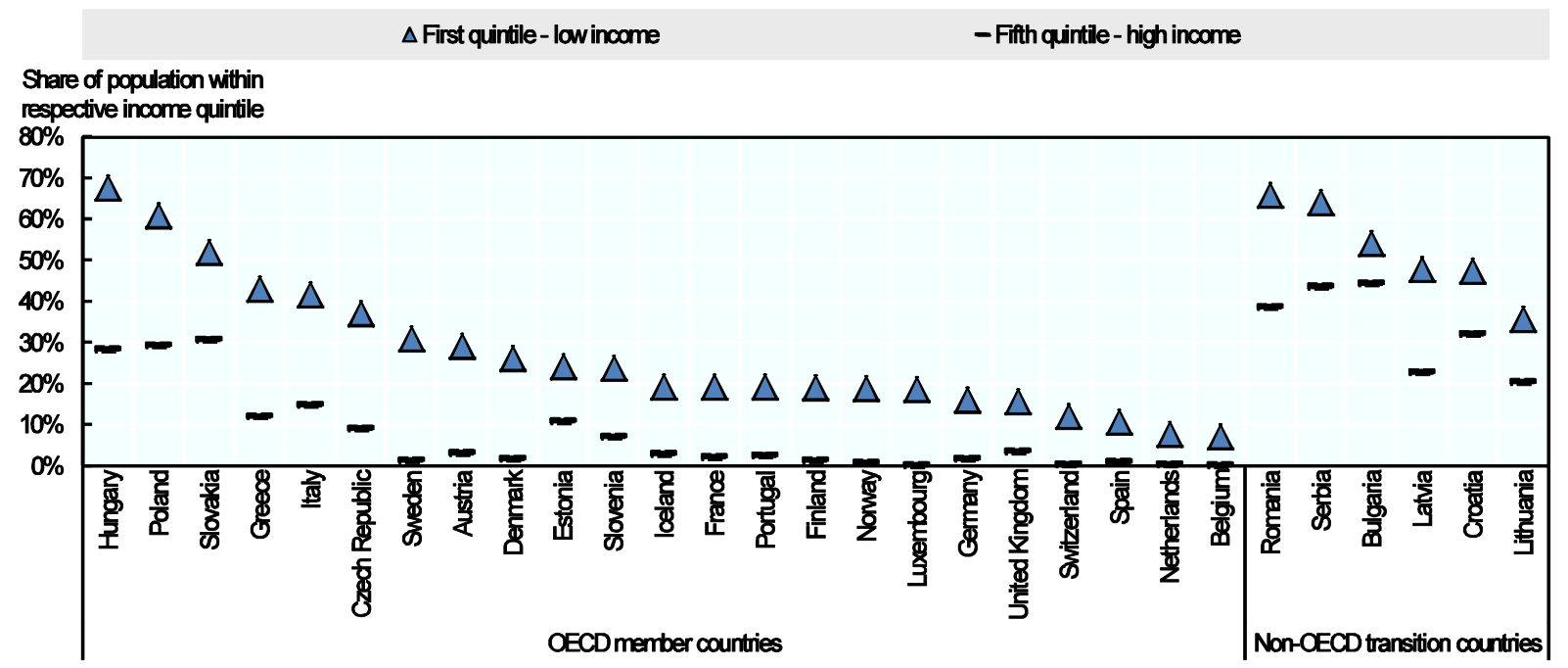

Note: The overcrowding rate is defined as the share of the population living in a household that does not meet the following criteria: one room for the household; one room per couple in the household; one room for each single person aged 18 or more; one room per pair of single people of the same gender between 12 and 17 years of age; one room for each single person between 12 and 17 years of age not included in the previous category; one room per pair of children under 12 years of age.

Source: Eurostat (2015a), EU-SILC: Overcrowding rate by income quintile - Total population (source: SILC) [ilc_Ivho05q], database: accessed February 2015

In addition to overcrowding, one-third of the poorest Polish households experience other measures of poor housing quality. About $20 \%$ of the lowest-income quintile experience both overcrowding and severe housing deprivation - that is, households living in overcrowded conditions in a dwelling that also exhibits at least one of the following measures: a leaking roof; no bath/shower and no indoor toilet; or insufficient lighting. This share is significantly higher than for households in the highest income quintile that experience severe housing deprivation in addition to overcrowding (4\%). In this regard, Poland fares better than Hungary ( $41 \%$ of households in the lowest income quintile and $6 \%$ of those in the highest income quintile) and registers similar levels as Italy (17\% and 4\%, respectively) among European OECD countries (Figure 6). Poland's housing deficit is thus of both a quantitative and a qualitative nature. 


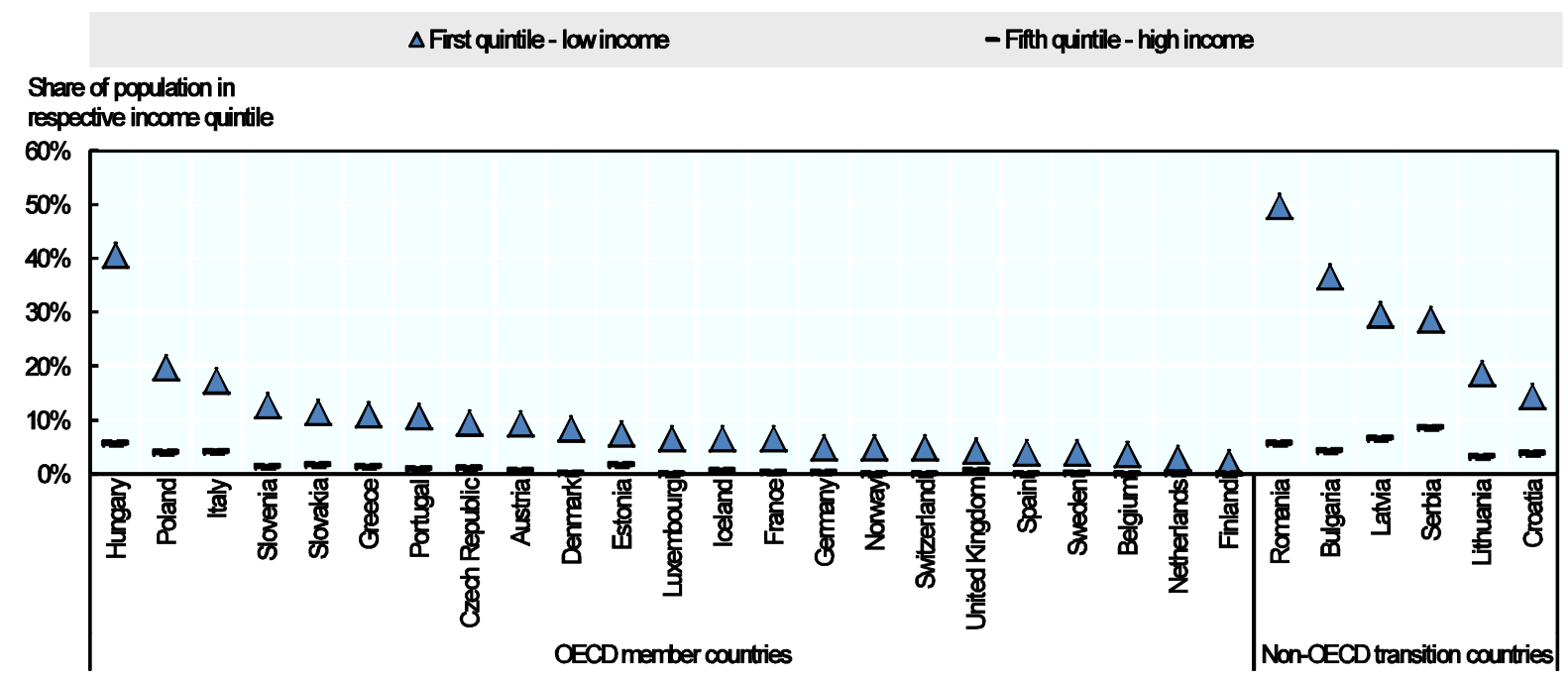

Note: The severe housing deprivation rate is defined as the share of the population living in a dwelling that is considered overcrowded and also exhibits at least one of the following housing deprivation measures of poor housing amenities: a leaking roof; no bath/shower and no indoor toilet; or insufficient lighting.

Source: Eurostat (2015b), EU-SILC: Severe housing deprivation rate by income quintile (source: SILC) [ilc_mdho06q], database: accessed February 2015.

Poor housing quality is often a challenge within the municipally-owned social housing stock, which, as discussed earlier, is the primary source of affordable housing stock for low-income households. Although tasked with the administration and maintenance of this stock, municipalities often lack the resources for proper maintenance. One reason is that, due to local politics, rental prices are often set too low to cover maintenance costs. Another reason is that income eligibility is only verified at time of entry into the unit; over time, this results in a large share of inhabitants living in municipal housing who could afford to pay higher rents.

Two other policy objectives, while present to some extent in existing policy documents, merit more explicit and consistent attention by housing policy makers: (i) increasing housing affordability and (ii) increasing the diversity of the housing stock to offer more choice (e.g. rental housing) to households. ${ }^{5}$ First, housing policy interventions do not appear to have made enough progress towards increasing housing affordability. A key problem is that increasing housing affordability has not been explicitly identified as a policy objective in recent years, despite evidence that it is a growing concern. Thus, even with the persistent housing deficit, there is also evidence of a large share of vacant dwellings in some areas, including in the capital region of Warsaw. While nationally, about $7 \%$ of the housing stock was vacant in 2011, the Mazowieckie voivodship, which hosts the country's capital Warsaw, was reported to have the highest inflow of population (with net migration per 1000 inhabitants of 2.7), but also a comparatively high share of vacant housing (13\%, based on data from the Central Statistical Office Poland, 2015c).

5. While affordability is not explicitly declared as main goal of housing policy, strategic documents from various ministries identify affordability as a problem and an area for increased action (e.g. Ministry of Labour and Social Policy (2013), Human Capital Development Strategy 2020 [Strategia Rozwoju Kapitatu Ludzkiego 2020], and Ministry of Infrastructure and Development (2010), "The main challenges, goals, and approach towards supporting the development of housing by 2020" [Główne problemy, cele i kierunki programu wspierania rozwoju budownictwa mieszkaniowego do 2020 roku]. 
Furthermore, the numbers do not suggest that in regions with a bigger housing shortage the vacancy rates are lower (Figure 7). This mismatch in a large housing deficit (the difference between the number of households and the number of occupied dwellings) and a large share of vacant dwellings suggests that the housing deficit is not only a quantitative problem (not enough houses), but may also be related to issues of affordability, quality or location of housing units. More analysis is required to understand the extent, causes and possible solutions related to housing vacancies in Poland.

Figure 7. Share of vacant dwellings and the housing deficit

2011

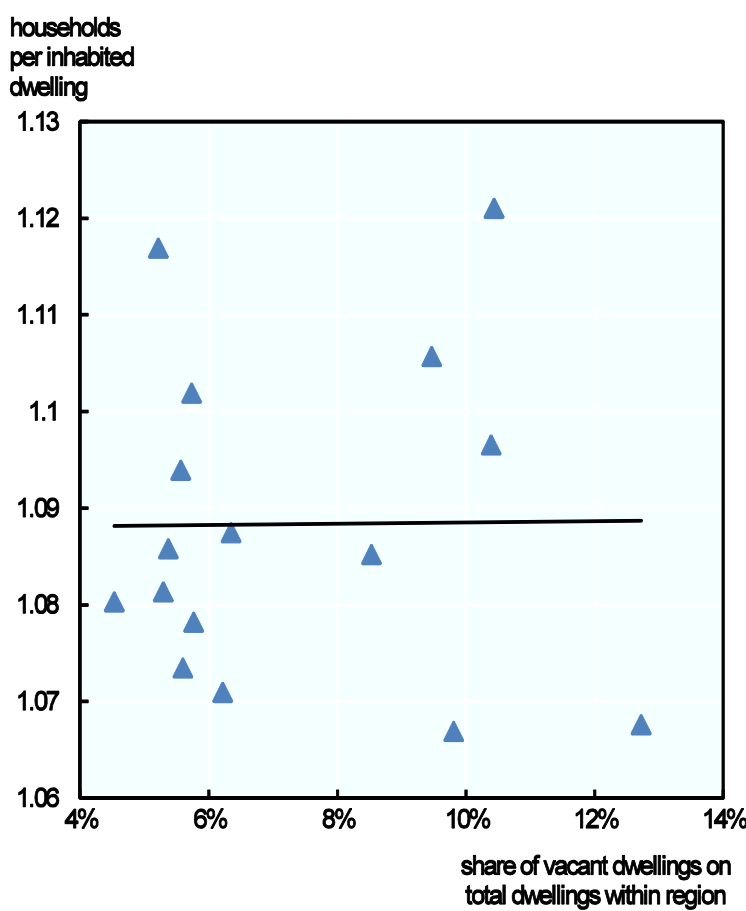

Source: Central Statistical Office Poland (2015c), Database: National Census - Census 2011: http://stat.gov.pl/bdlen/app/strona.html?p name=indeks (accessed April 2015).

There are conflicting accounts of the effects of recent policy interventions on affordability. On a broad basis, Radzimski (2014) summarises the unclear relationship in the literature between housing subsidies and affordability. Herbst (2012) finds that the Family's Own Home programme, which offered subsidies for commercial credits in a context of rigid supply, ultimately put pressure on prices and provided de facto financial support to developers and banks, citing evidence that up to two-thirds of the total programme spending went to developers and banks. The Ministry of Infrastructure and Development has however not found any evidence to support these findings.

Most public expenditures on housing at central level, in addition to tax instruments related to housing, historically support home ownership, with rental programmes receiving less consistent attention in the overall policy framework. The policy preference for home ownership is not unusual in OECD countries (see e.g., Andrews and Sánchez, 2011; OECD, 2015b, 2013a). In Poland, the high rate of home owners is both a product of history and a result of continued policy support to home ownership since the transition period. As in other transition countries, mass privatisation of housing units to their residents led to high ownership rates, including among lower-income groups. About $84 \%$ of the Polish population live in owner-occupied housing, of which the majority $(74 \%)$ has no outstanding mortgages or housing loans (Figure 8A and 8B). Within the population at risk of poverty (households below $60 \%$ of the median 
equivalised income), ownership rates are still high (76\%), with a very low share (4\%) with a housing loan or mortgage, a result of mass housing privatisation following the transition. The high ownership rate within Poland implies an underdeveloped rental market, which in turn could affect residential and labour mobility (Nickell and Layard, 1999; Box 8, see also Oswald, 1996; Sánchez and Andrews, 2011).

Figure 8. Housing tenure in OECD countries, 2013

\section{A. Total population}

口OWner, with mortgage or loan $\square$ Ouner, no outstanding mortgage or housing loan

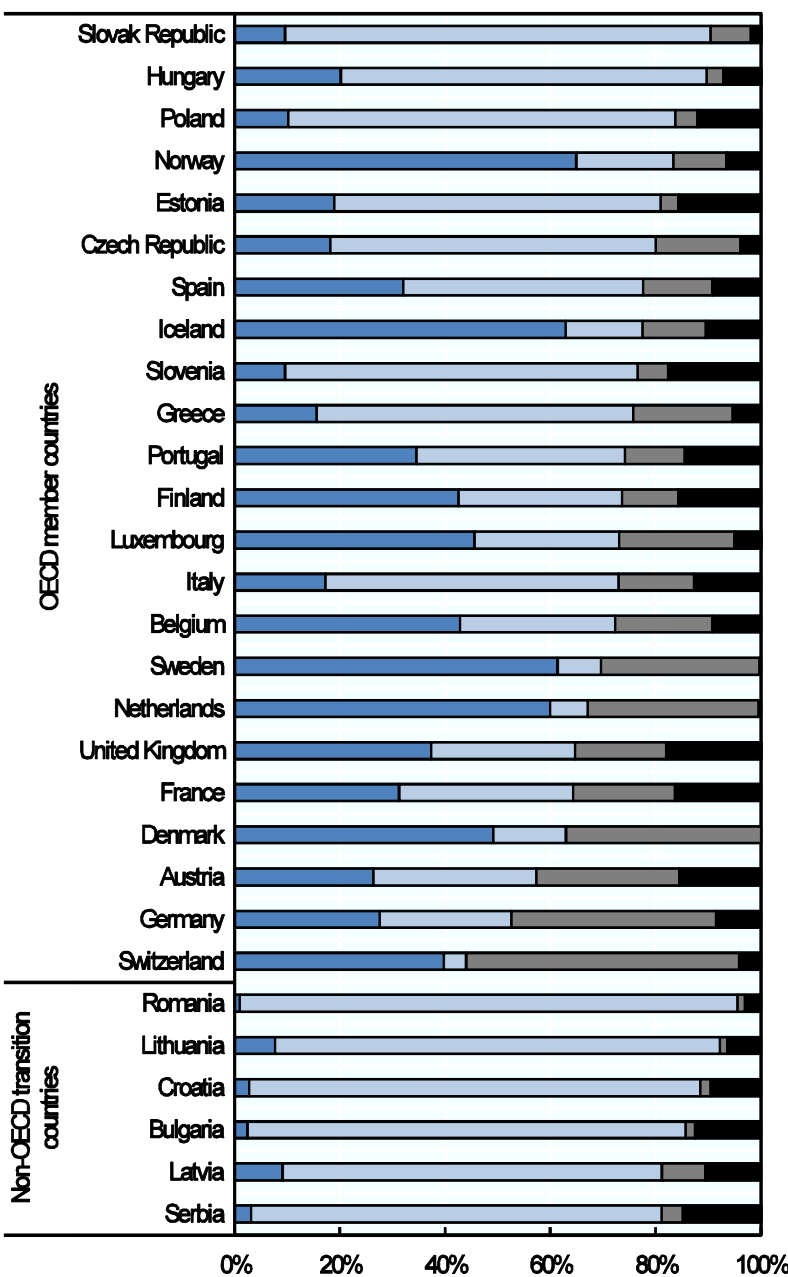

\section{B. Population at risk of poverty}

口Tenant, rent at market price $\quad$-Tenant, rent at reduced price or free

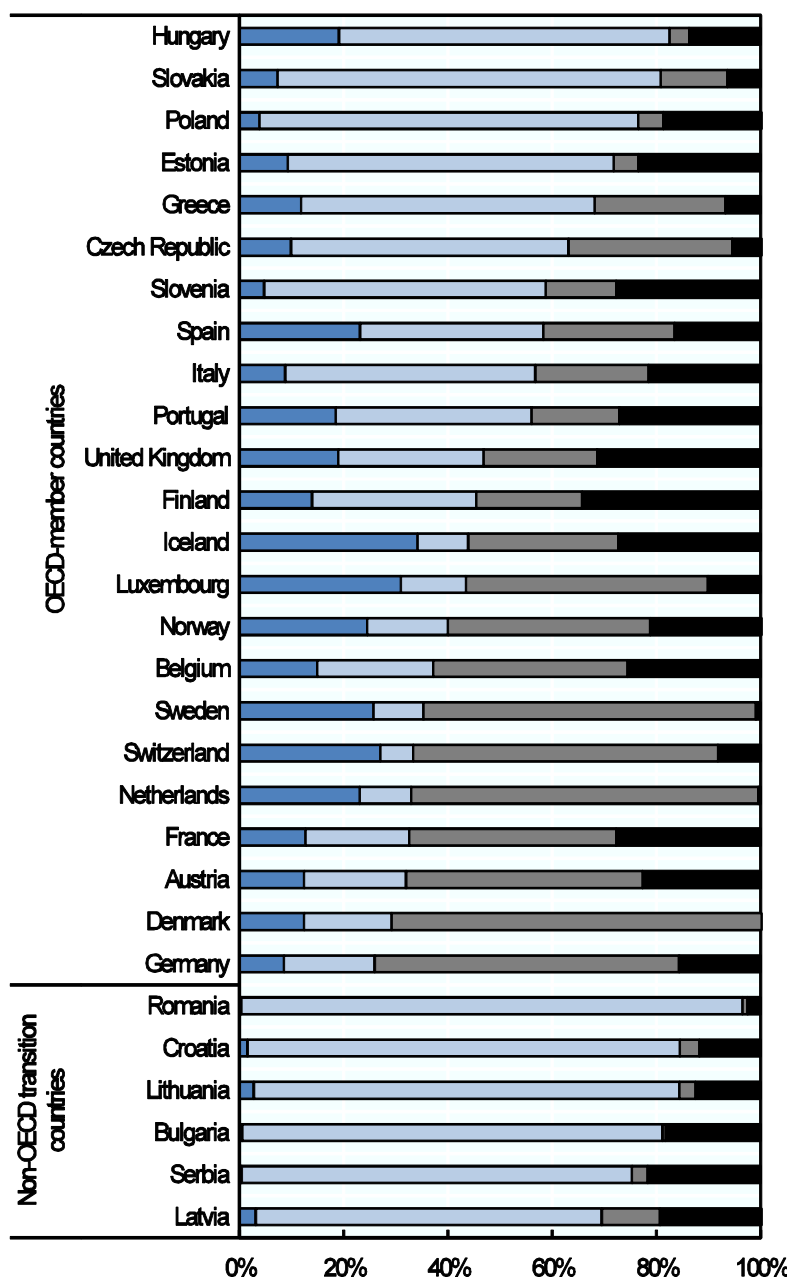

1. Population at risk: below $60 \%$ of median equivalised income

Source: Eurostat (2015c), based on EU-SILC: Distribution of population by tenure status, type of household and income group (source: SILC) [ilc_lvho02, database, (accessed 3 February 2015).

In 2015, nearly $70 \%$ of total national government spending on housing aimed to support home ownership programmes (Housing for the Young and Family's Own Home); just 5\% of national resources were spent with the objective of supporting rental housing, through a programme targeting very lowincome and vulnerable households. The major rental programme, TBS, was discontinued in 2009; at the time of writing, the government was in an advanced stage of discussions for a programme to replace the TBS. At the same time, the National Development Bank (BGK) has developed a Rental Housing Fund with a budget of PLN 5 billion to support rental housing. 


\section{Possible directions for Poland}

Policy makers should begin by defining clear, strategic objectives for housing policies overall, as well as for each specific policy instrument. Policy objectives should be based on a clear understanding of the market failure or policy problem that needs to be addressed. For example, policy objectives may aim to address the problem of a shortage of affordable housing for low-income households in large cities, or the challenge of an underdeveloped rental market. For instance, this type of assessment was undertaken in Ireland as part of a process to review the efficiency and effectiveness of the country's housing programmes and to determine which instruments should continue to receive national support (Table 4). Such an assessment at regular intervals is also important to determine to what extent social, economic, environmental factors have changed in the broader policy environment since the introduction of the policy that may have a bearing on policy design and objectives.

Table 4. A review of housing policy instruments in Ireland: Rationale for continuing existing policy measures

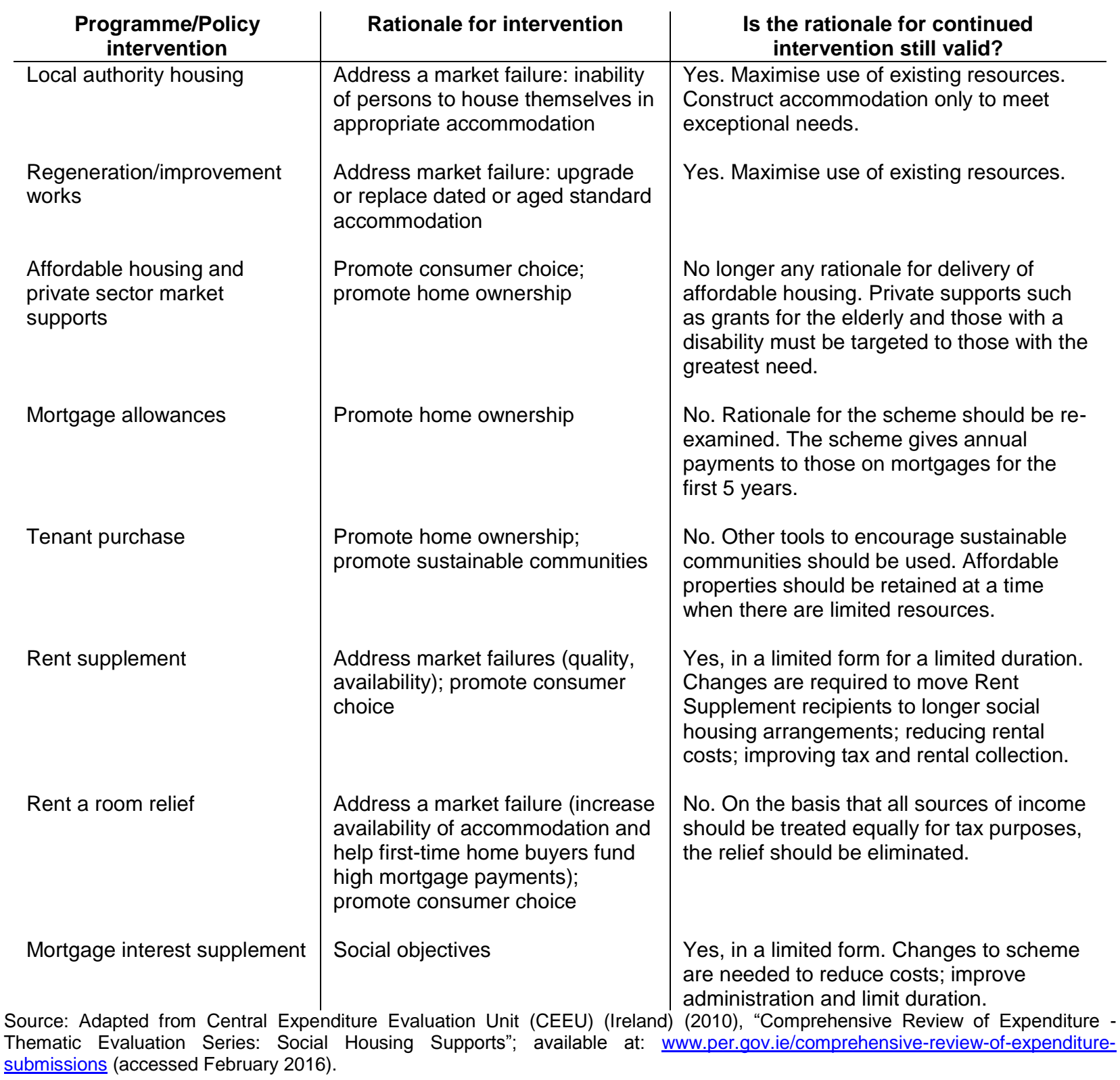


A selection of different housing policy objectives across OECD countries is summarised in Box 2. Policy objectives for Poland should obviously be defined based on the challenges and needs specific to the Polish context. Even so, it may nonetheless be useful for Polish policy makers to understand how other OECD countries have formulated housing policy objectives and, with the aim of contemplating the range of possible policy instruments to address a given challenge, to what extent some of the challenges facing Poland are shared across the OECD.

\title{
Box 2. How have different OECD countries identified affordable and social housing policy objectives?
}

\author{
Austria \\ - Increase housing affordability \\ - $\quad$ Reduce energy consumption in new construction and existing housing stock \\ - Sustain housing construction on a high level to meet demand \\ - Strategic development of cities and villages \\ - Housing for the elderly \\ Chile
}

- $\quad$ Reduce the housing deficit in the most vulnerable sectors and support the efforts of the middle class in their housing aspirations through the delivery of housing solutions with an emphasis on quality, integration and equity

- Location of housing with a social integration criteria

- Improvement of deteriorated housing so as not to increase the housing deficit

- Attention to rural areas and recognising their specific features

- Special attention to reducing informal settlements, and not induce their creation

Estonia

- Create a suitable environment to support the development of an affordable housing sector (including review of the legislative and taxation system)

- Develop different strategies to improve co-operation between national, local governments and the private sector

- Take action based on strategies to activate the affordable housing sector

France

- Facilitate access to home ownership

- Simplify construction regulations and develop innovation

- Boost the supply of new housing, social housing and intermediate housing

- Free up public and private land for development

- Renovate/update housing

\section{Germany}

- Strengthen housing construction and the construction of social (rental) housing to meet the rising demand in agglomerations

- Affordable rents/housing costs, especially for households with low income

- Manage demographic change particularly through age-based modifications to the housing stock 


\section{Box 2. How have different OECD countries identified affordable and social housing policy objectives?}

(continued)

Ireland

- Enable all households to access good quality housing appropriate to their household circumstances and in their particular community of choice. In so doing, we will reduce the number of households on social housing waiting lists.

- The Homelessness Policy Statement's overall objective is to bring an end to long-term homelessness.

- Build a competitive, innovative, dynamic, safe and sustainable construction sector

Mexico

- Curb urban sprawl

- Improve the quality of rural and urban housing and its surrounding environment, while reducing the housing deficit

- Diversify the supply of quality housing solutions

- Generate optimal credit and subsidy schemes for housing solutions

- Strengthen inter-institutional co-ordination across the three levels of government

\section{United States}

- Strengthen the housing market to bolster the economy and protect consumers

- Meet the need for quality, affordable rental homes

- Use housing as a platform to improve quality of life

- Build strong, resilient and inclusive communities

Source : Ministry of Housing, Territorial Equality and Rural Areas (France) (2015), Politiques du logement [Housing Policies], available at: www.territoires.gouv.fr/actions-pour-la-relance-de-la-construction ; Salvi del Pero, A., et al. (2016), "Policies to promote access to good-quality affordable housing in OECD countries", OECD Social, Employment and Migration Working Papers, No. 176, OECD Publishing, Paris. http://dx.doi.org/10.1787/5jm3p5gl4djd-en.

2) Who are the target beneficiaries of housing interventions, and to what extent do housing instruments reach the target beneficiaries?

\section{Rationale}

A clear understanding of the desired beneficiaries to be targeted by different housing instruments is a critical step in the policy making process. As discussed in previous sections, recent policy interventions in Poland, such as Family's Own Home, were developed as "pro-family" policies aiming to provide financial support for families to purchase their first home. Other programmes, such as emergency housing for the very low-income, homeless and vulnerable populations are the targets of a separate policy instrument, cofinanced by the national and individual municipal governments. Different programmes may be more appropriate for different groups (e.g. expanding rental programmes for low-income households, young people entering the workforce) and in different parts of the countries (e.g. rental programmes may be in greater need in urban areas with more employment opportunities, for instance).

\section{Assessment of the situation in Poland}

Based on eligibility criteria, housing instruments in Poland primarily target either the lowest-income households or medium to high-income groups. There is however a considerable gap in the reach of housing instruments for households that fall in between. In a recent analysis of affordable housing policies by 
income groups, the Ministry of Infrastructure and Development found that about $43 \%$ of the population aged 25-35 years still lived with their parents in 2012 due to a lack of affordable housing alternatives (Ministry of Insfratructure and Development, 2014). In terms of housing affordability, Polish households spend a larger share (23\%) of their disposable income on housing than the OECD average, and equivalent to levels in Italy, Luxembourg and Switzerland (Figure 9). According to estimates by the Ministry, the purchasing power of the average monthly wage to buy a house is between two and four times lower in Poland than in Western European countries (Ministry of Infrastructure and Development, 2010). High construction costs and high prices for new housing exclude many low-income households from the commercial housing market.

Figure 9. Household expenditure on housing in OECD countries, 2012

Percentage of the household gross adjusted disposable income spent on housing

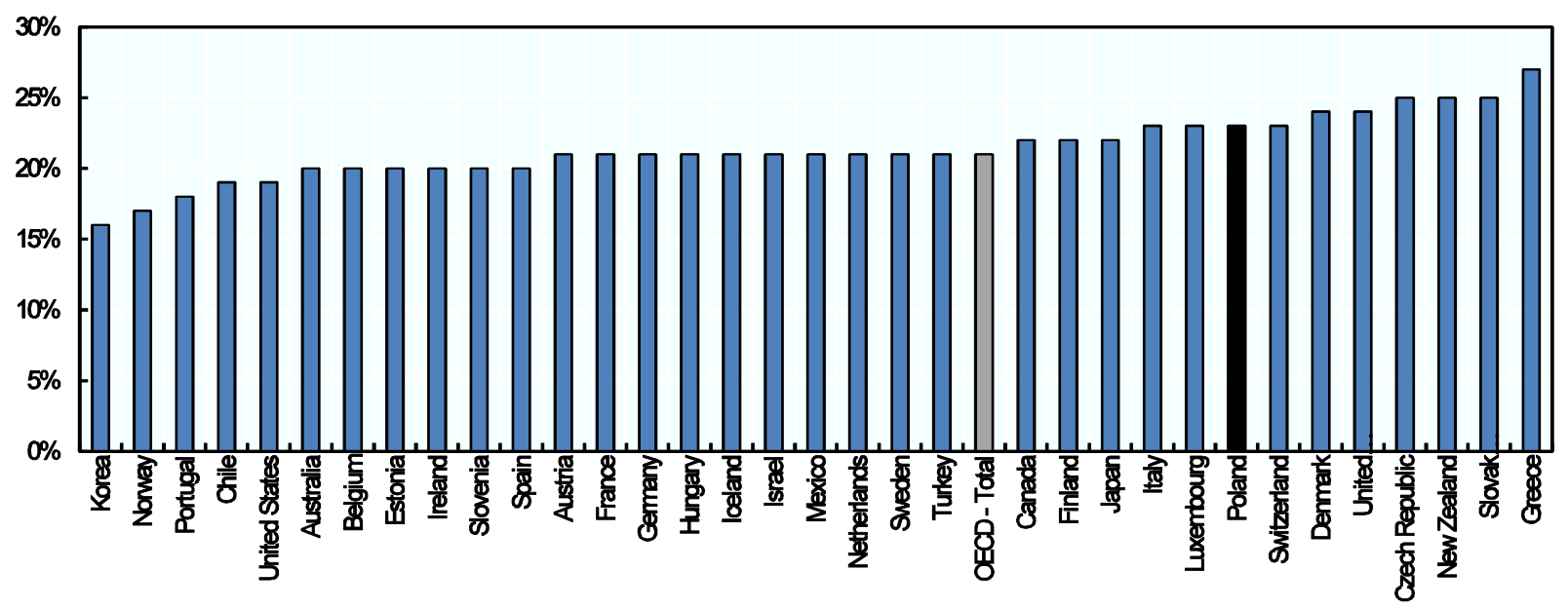

Note. The reference year is 2012 with the exception of 2011 for Japan, New Zealand, the Russian Federation, Switzerland; 2010 for Canada.

Source: OECD (2014b), OECD Better Life Index 2014, www.oecdbetterlifeindex.org.

Households with children have particular difficulty in purchasing adequate homes from the commercial market. In a 2014 study, the Ministry of Infrastructure and Development simulated the affordability of one-square meter of a dwelling financed with commercial credit for different income groups and family types (Table 5). Households with children - particularly single-parent households or households with two or more children - face the largest credit constraints in accessing affordable housing. With the exception of a dual-income household and one child, low-income households with children are not able to afford a commercially financed home. The purchase of housing only becomes affordable for households with children earning about the median income or more - though the housing size for a family with children remains largely inadequate. For households with three children, only the highest-income households are able to afford to buy adequate housing via commercial lending: those in the 8th income decile and above. 
Table 5. Number of square metres of commercially-financed credit affordable for a given household structure

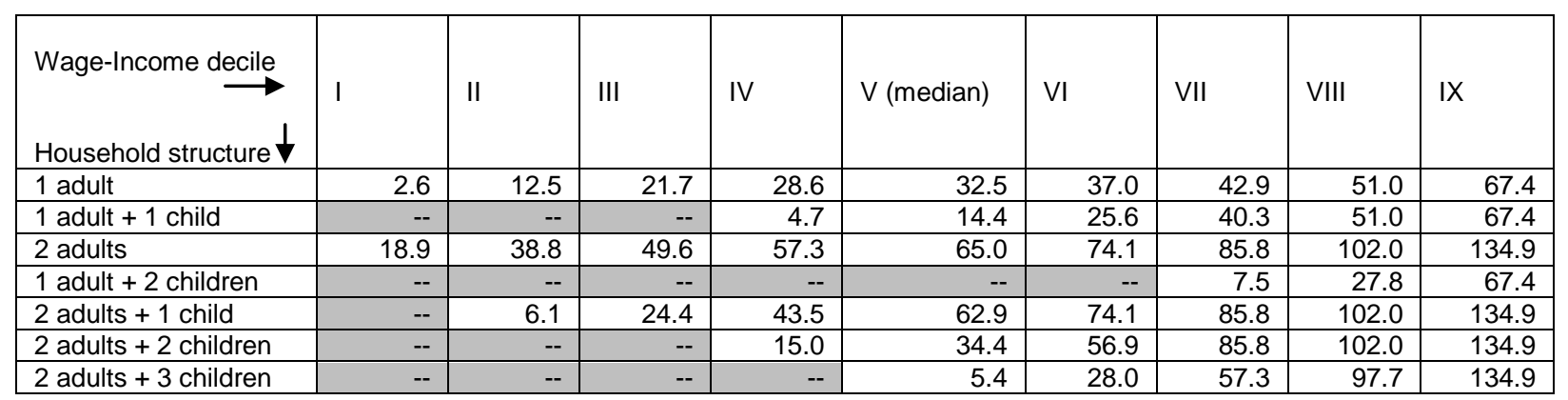

Note: "--" indicates that no income left for payments to the bank because social minimum consumption was equal or exceeded net income. Assumptions for simulations: As information on average transaction prices are not available, the average price of 1 square meter of dwelling handed over for use is used as a proxy for the average price of a flat; the effective interest rate from the end of 2013 (4.7\%); the credit runs for 25 years; the amount of a credit available depends on the earnings and the banking S-recommendation (monthly payment to the bank equals $40 \%$ of net income); in families with 2 adults, it is assumed that both work; only income from work is taken into account (by deciles).

Source: Ministry of Infrastructure and Development (2014), "Analysis of the availability of credit for households aged 25-34" [Analiza dostępności kredytów mieszkaniowych dla gospodarstw domowych w wieku 25-34 laf]; wage-income deciles refer to the year 2012, with the adjustment to reflect the fact that people aged 25-34 earn approx. 93\% of the average wage.

While local governments are primarily responsible for providing social housing for the lower income groups (with the exception of national government participation in emergency housing ${ }^{6}$ ), housing instruments administered by the national government tend to target households at the upper end of the wage distribution. Less than $20 \%$ of the population aged 25-34 years is eligible for housing allowances and/or renting a municipally-owned social housing unit; less than $10 \%$ is eligible for emergency housing, also managed by local government (Figure 10 and Table 6). As a result, young adults in the third to seventh income deciles are not targeted by any housing policy instrument. Furthermore, housing allowances, another policy instrument aimed at lower income households, are only allocated to persons that already rent or own a flat. This instrument therefore has only a limited impact on fulfilling the housing needs of those who do not yet have access to their own dwelling.

On the other end of the income spectrum, only 25-34 year olds with medium and higher salaries (seventh to eighth decile) are eligible to benefit from the Housing for the Young programme. A similar income group can be assumed to have benefited from the predecessor, the Family's Own Home programme. Moreover, the commercial housing market is only an option for the two highest salary deciles (Ministry of Insfratructure and Development, 2014). In short, housing policies are leaving roughly 50\% of the population aged 25-34 years old without access to any instrument of public housing policy. For those aged over 34, no national subsidies are in place; they have recourse only to the commercial market for purchasing a home.

6. The national government provides co-financing to municipalities for emergency housing for very lowincome, the homeless, and other vulnerable populations - but such national funding requires participation of $50-70 \%$ on the part of municipalities. 
Figure 10. Eligibility levels for respective housing instruments, by wage-income decile

Single persons aged 25-34 years old

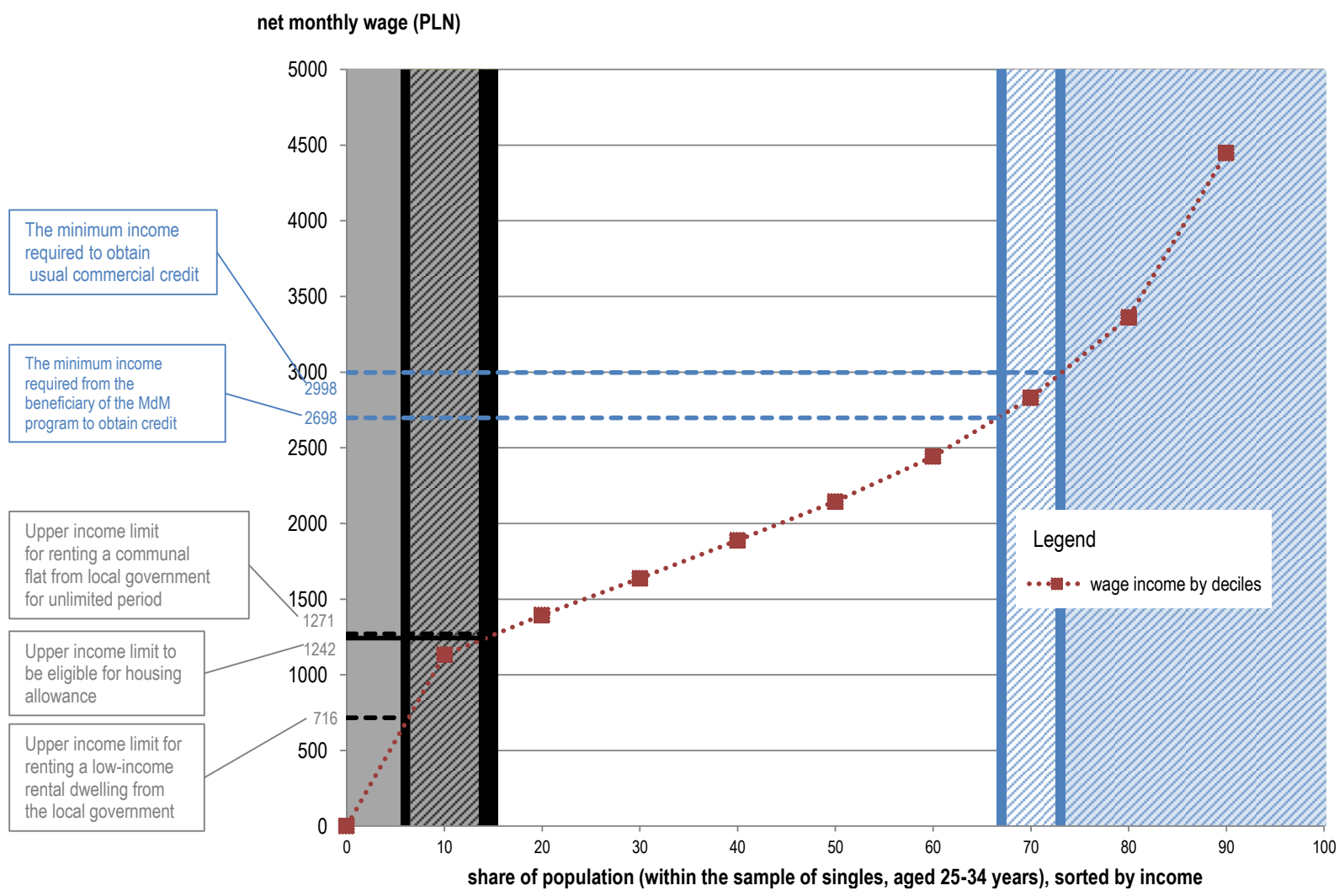

Note: Assumption for the analysis: flat size: 50m2; commercial credit: 25 years, interest: WIBOR+2p.p. (-4.7\%), population under consideration: Singles, aged 25-34 years.

Source: Ministry of Infrastructure and Development (2014), "Analysis of the availability of credit for households aged 25-34" [Analiza dostępności kredytów mieszkaniowych dla gospodarstw domowych w wieku 25-34 lat]. 
Table 6. Eligibility levels for respective housing instruments, by wage-income decile

Single persons aged 25-34 years old

\begin{tabular}{|c|c|c|c|c|c|c|}
\hline & & \multicolumn{5}{|c|}{ Eligibility for respective housing instrument } \\
\hline & & \multicolumn{3}{|c|}{ Municipal instruments } & $\begin{array}{c}\text { National } \\
\text { instruments }\end{array}$ & $\begin{array}{c}\text { Commercial/ private } \\
\text { instruments }\end{array}$ \\
\hline Decile & $\begin{array}{l}\text { Net monthly wage } \\
\text { (PLN) } \\
\text { Net income } \\
\text { threshold }\end{array}$ & $\begin{array}{l}\text { Renting low- } \\
\text { income rental } \\
\text { dwelling from } \\
\text { the local } \\
\text { government } \\
\text { ("emergency } \\
\text { housing") } \\
716\end{array}$ & $\begin{array}{c}\text { Renting a } \\
\text { municipally- } \\
\text { owned social } \\
\text { housing flat } \\
\text { for unlimited } \\
\text { period (“social } \\
\text { housing") } \\
1271\end{array}$ & $\begin{array}{c}\text { Housing } \\
\text { allowance } \\
\\
1242\end{array}$ & $\begin{array}{l}\text { Minimum income } \\
\text { required for } \\
\text { beneficiaries of } \\
\text { Housing for the } \\
\text { Young } \\
\text { programme to } \\
\text { obtain credit }^{1,4} \\
2698\end{array}$ & $\begin{array}{l}\text { Minimum income } \\
\text { required to obtain } \\
\text { usual commercial } \\
\text { credit }^{1}\end{array}$ \\
\hline $\begin{array}{l}\text { I } \\
\text { II }\end{array}$ & $\begin{array}{r}0-1132 \\
1133-1395\end{array}$ & Yes (some) & $\begin{array}{l}\text { Yes } \\
\text { Yes (some) }\end{array}$ & $\begin{array}{l}\text { Yes } \\
\text { Yes } \\
\text { (some) }\end{array}$ & & \\
\hline $\begin{array}{l}\text { III } \\
\text { IV } \\
\text { V - } \\
\text { media } \\
\text { n } \\
\text { VI }\end{array}$ & $\begin{array}{llll}1 & 396 & -1 & 637 \\
1 & 638 & -1 & 889 \\
1 & 890 & -2 & 145\end{array}$ & & & & & \\
\hline $\begin{array}{l}\text { VII } \\
\text { VIII } \\
\text { IX } \\
X\end{array}$ & $\begin{array}{r}2443-2829 \\
2830-3362 \\
3363-4447 \\
4448 \text { and more }\end{array}$ & & & & $\begin{array}{l}\text { Yes (some) } \\
\text { Yes } \\
\text { Yes } \\
\text { Yes }\end{array}$ & $\begin{array}{l}\text { Yes (some) } \\
\text { Yes } \\
\text { Yes }\end{array}$ \\
\hline
\end{tabular}

Notes: (1) Such as monthly payment to the bank $=40 \%$ of net income. (2) In monthly PLN. (3) At least $5 \%$ in $2014,10 \%$ in $2015 ; 15 \%$ in 2016; $20 \%$ in 2017. (4) These estimates assume that the price of the flat fulfils the programme criteria of maximum price (the price of 1 square meter is not higher than average cost of amortisation of 1 square meter of a dwelling in a given local district and the size of a dwelling not higher than 75 square meters (100 square meters for a house)).

Source: Ministry of Infrastructure and Development (2014), "Analysis of the availability of credit for households aged 25-34" [Analiza dostępności kredytów mieszkaniowych dla gospodarstw domowych w wieku 25-34 laf].

Despite the small share of eligible beneficiaries, instruments may not always be reaching their intended targets, for different reasons. In the case of municipally-owned social housing units, due to high demand, many of those who are eligible for housing assistance do not actually receive it. In 2011, about 135000 households were on waiting lists for some form of social housing (either emergency housing or social housing), of which 79000 households were waiting for emergency dwellings (Ministry of Insfratructure and Development, 2014). Further, due to strong tenure protection regulations, the rotation in municipal dwellings is very low: each year municipalities sign around 25000 new rental contracts, of which in 2011, $42 \%$ were for households on the waiting list, $23 \%$ for households evicted from previous dwellings, and the remaining 35\% for family members of a deceased tenant eligible to remain in the dwelling even if they do not meet the social criteria (Ministry of Insfratructure and Development, 2014). The average waiting time for some form of social housing is 17 years. The opportunities for moving into an own dwelling for 25-34 year olds at the lower end of the income distribution are thus slim. In another case, Family's Own Home, preliminary analysis suggests that a large share of the actual beneficiaries (single households) were not the targeted beneficiaries (households with children), resulting partly from the change in eligibility criteria when a new government came into office and softened the original "profamily" objective (Radzimski, 2014).

Similarly, an assessment of the formerly active social rental housing programme TBS found that the original social targeting goal was not achieved; rather, most units were allocated to households with middle or high incomes (Brzeski et al., 2009). The financial structure of the programme resulted in the need for TBS companies to secure additional capital funding, most of which came from municipalities or the 
tenants themselves; as a result, tenants were selected "based on their financial capacity to invest in such a down payment [rather] than on their social status or need for affordable rental housing" (Brzeski et al., 2009: 6).

In sum, the targeting of beneficiaries would appear in some cases to be by design (e.g. higher-income households for the Housing for the Young programme) while in others may be an unintended consequence of policy design (e.g. higher income households the primary beneficiaries of the former social rental housing programmes, resulting from the financial structure of the programme). Yet there are also broader housing trends at play, including the evolution from co-operative to commercial housing development, and the slow development of the mortgage market.

\section{Possible directions for Poland}

To address the housing affordability gap, and especially in a time of fiscal constraints, governments both at the national and local level - might look to concentrate a larger share of housing assistance to households in greatest need. In this sense, recent programmes that have primarily benefitted medium- to higher-income groups (e.g. TBS social rental housing programme; Family's Own Home) may not be the most effective use of limited public resources on housing.

It is also important to keep in mind that regular efforts are needed to ensure that the target beneficiaries are continuing to be served by a given policy over time. In their review of the TBS programme, Brzeski et al. (2009) point out that better targeting of the beneficiaries requires not only that income levels should be strictly controlled at the time of housing allocation (with the existence and application of rules that clearly prioritise low-income households); it is also essential to define and enforce rules to successively adjust the rent paid by tenants whose income has grown past the ceiling over time, thereby allowing municipalities to allocate scarce resources to needier households. These issues are expected to be addressed in the new programme.

\section{3) Have a range of policy options been considered, including those that do not imply financial obligations as well as the "do nothing" alternative?}

\section{Rationale}

In light of the limited fiscal space for developing strategic housing programmes (as discussed above), it is important that policy makers evaluate a full range of policy options - including those that do not imply financial obligations, as well as the "do nothing" alternative.

\section{Assessment of the situation in Poland}

First, there is ample evidence to suggest that regulatory policies could be reviewed to have a considerable impact on the supply of rental housing in Poland. Burdensome tenant regulations are an important obstacle to a larger rental market in Poland; this challenge is identified in numerous public documents (see, among others, Ministry of Infrastructure and Development, 2010; Ministry of Labour and Social Policy, 2013) and academic papers (see, for instance, Brzeski et al., 2009; Radzimski, 2014). Radzimski characterises the "over-regulation of the private rental market" as a key factor in discouraging potential landlords and limiting the supply of rental housing. Indeed, Poland has some of the most restrictive tenant-landlord regulations in the formal rental market across OECD countries (Andrews and Sánchez, 2011). Meanwhile, public authorities do not supervise contracts in the informal rental sector. While these types of regulatory interventions may not be effective substitutes for public spending to boost the rental market, it is clear that they could strongly support such expenditures and ensure an even greater impact of these limited public resources. 
Second, policy makers should also carefully evaluate each policy proposal against a "do nothing" alternative as an important means of determining which interventions are susceptible to generating the largest impact. For instance, in the case of Family's Own Home, it is unclear whether the households who ultimately benefitted from the programme would have invested in a new home without national government assistance. On the other hand, it is conceivable that the modernisation programme has provided assistance for energy efficiency retrofits that would not have occurred without support from the national government (and, more broadly, without higher energy prices that would provide sufficiently strong incentives for building owners to undertake these projects without national government support).

\section{Possible directions for Poland}

More could be done to generate more resources for municipal governments to upgrade their housing stock through regulatory reforms, for instance, particularly via updating or, in some cases, simply enforcing existing regulations with respect to the municipally-owned social housing stock. More regular income verifications should be implemented to ensure that the neediest households are taking advantage of the limited municipal housing supply (see, by extension, the recommendations for the former TBS programme outlined in Brzeski et al., 2009).

Each proposed policy intervention should be weighed against others, including the "do nothing" alternative to determine whether intervention itself and the level of resource allocation are justified. The authorities in the United Kingdom have developed a "Green Book" to assist policy makers in determining which policy instruments should be selected among a range of options; a summary of these consideration are included in Box 3.

\section{Box 3. Appraising the range of policy options: Lessons from the "Green Book" in the United Kingdom}

To assist policy makers in determining which policy instruments should be used, authorities in the United Kingdom have developed a "Green Book" of Appraisal and Evaluation in Central Government. One critical step in the process is the assessment of a wide range of options in order to set the parameters of an appropriate solution. From this range of options, a shortlist may then be created to keep the process manageable, by applying the techniques summarised below to high level estimates or summary data. The "do nothing" option should always be carried forward in the shortlist, to act as a check against more interventionist action.

The appraisal may develop as follows:

- Identify and value the costs of each option

- Identify and value the benefits of each option

- If required, adjust the valued costs and benefits for

- Distributional impacts (the effects of proposals on different sections of society)

- Relative price movements

- Adjust for the timing of the incidence of costs and benefits by discounting them, to obtain their present values

- If necessary, adjust for material differences in tax between options

- Adjust for risk and optimism to provide the Base Case, and consider the impacts of changes in key variables and of different future scenarios on the Base Case

- Consider unvalued impacts (both costs and benefits), using weighting and scoring techniques, if appropriate

Source : Adapted from Office of the Treasury (UK) (2011), "The Green Book: Appraisal and Evaluation in Central Government", available at: www.gov.uk/government/uploads/system/uploads/attachment data/file/220541/green book complete.pdf. 
4) To what extent are monitoring and evaluation systems in place to enable an effective assessment of policy interventions? What measurable impacts (outputs, outcomes) can be attributed to specific housing instruments?

\section{Rationale}

Indicators play a central role in the monitoring and evaluation process by generating regular and objective feedback about progress towards policy objectives. Indicators are quantitative representations of the conditions in a policy field. They can be used as a tool to examine the effects of policies and they provide crucial information for policy makers to judge the effectiveness of policies and to make adjustments where required. Compared to many other feedback mechanisms, well-designed indicators have the advantage that they provide easily comprehensible information. Thereby, they can form a factual basis upon which informed political decisions can be made (for more on this, see Barca and McCann, 2011; OECD, 2014c; Schumann, 2016).

There are three types of indicators: input, output and outcome (Box 4). Input indicators measure the policy effort (the level of resources allocated to a policy programme: e.g. money, time, staff resources); output indicators can be used to monitor policy efficiency as it relates the outputs to their inputs (what policies produce as a result of the inputs: e.g. number of houses built); outcome indicators measure policy effectiveness by linking the output to the intended objectives (what results are achieved due to the policy: e.g. the share of households paying more than $30 \%$ of their income on housing-related expenditures).

\section{Box 4. Using indicators to monitor policies}

Three types of indicators: input, output and outcomes

There are three main types of indicator that can all be part of a framework to monitor the effectiveness of policies: Input, output and outcome indicators. Input, output and outcome indicators can all be part of a framework to monitor the effectiveness of policies, but it is important that each type of indicator is used to monitor only the aspects of a policy it is designed to monitor. In particular, it is essential to avoid using output indicators in order to measure outcomes. The Figure below provides an overview of the three types of indicators, followed by a more detailed description of each type.

\section{Three types of indicators}

\section{Input Indicators (Monitor Effort)}

Measure resources spent on policies (money, staff, time,...)

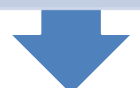

Output Indicators (Monitor Efficiency)

Measure what policies produce by using inputs

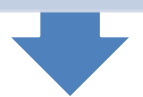

Outcome/Result Indicators (Monitor Effectiveness)

Measure what results are achieved by the outputs 


\section{Box 4. Using indicators to monitor policies (continued)}

- Input indicators measure the level of resources used by a policy, and as such they can provide a measure of the effort that is devoted to pursuing a policy. They do not give any information as to whether the resources are efficiently spent or whether a policy is effective in achieving an objective, and it is never possible to monitor policies using input indicators alone.

- $\quad$ Output indicators measure the quantities that are directly generated by a policy. Output indicators do not provide any information about whether the outputs of a policy are effective in achieving the desired outcomes of a policy - or in other words, if the outputs do what they are supposed to do. Consequently, the primary purpose of output indicators is to monitor whether a policy is efficient in producing outputs. They cannot monitor the effectiveness with which the policy addresses its objective(s).

- $\quad$ Outcomes are the results that are supposed to be achieved through the outputs that are generated by a policy. They are the real motivation behind a policy. A policy has to produce an output, which is able to influence the outcome in the desired direction. An outcome indicator always has a normative component in the sense that (within a reasonable range) a movement in one direction is considered a positive development and a movement in the other direction is considered a negative development. This implies that it is not possible to develop meaningful indicators without having previously specified policy objectives. It is essential to understand the differences between outcome and output indicator and to avoid using output indicators to measure outcomes.

\section{Distinguishing outcome from output indicators}

Distinguishing outcome from output indicators and using them according to their purpose is a crucial aspect when using indicators to monitor policies. Generally, outputs refer to something that a policy produces directly with the inputs that are provided. In contrast, outcomes are something that should be achieved by the outputs that are produced. Usually, there is certainty about what outputs are produced by a policy, but it is generally not certain if the outputs cause a certain outcome. For example, a policy that aims to build new schools is virtually guaranteed to produce new school buildings as outputs. However, it is not clear if the new schools improve the learning outcomes of students. Outcome indicators always measure something that is not perfectly assured to be achieved by a policy (thus the need for them). There might or might not be better learning outcomes as a result of school construction. In contrast, if there is any uncertainty related to outputs, it is usually only regarding the quantity and quality of outputs produced. Even though it is clear that a policy to build schools will produce new school buildings, it might not be clear how many will be built nor of what quality they will be.

Source : Schumann, A. (2016), "Using Outcome Indicators to Improve Policies: Methods, Design Strategies and Implementation", OECD Regional Development Working Papers, 2016/02, OECD Publishing, Paris. http://dx.doi.org/10.1787/5jm5cgr8j532-en.

\section{Assessment of the situation in Poland}

The principal challenge in Poland in evaluating the effectiveness of housing policies and by extension, public spending on housing, is the absence of indicators to monitor policy progress. An exception is the existence of housing monitoring programmes that exist in some towns; however, a broad monitoring programme of housing interventions at national level does not exist. The shortage of evidence on policy outcomes is widely acknowledged in the literature (see Brzeski et al., 2009; Herbst, 2012; Radzimski, 2014). As a result, it is difficult to evaluate the extent to which public spending on housing in Poland has been effective. Most data that have been collected tend to focus on input and output measures, rather than outcome measures, which is also problematic.

Figure 11 summarises the programmes for which there is some information available regarding the input and output of housing spending in Poland. Input measures are considered as the national budget allocated to a given programme; output measures are defined different for different programmes (based on information provided by the Ministry), such as the number of houses built and/or under construction, the 
loan take-up within a programme, or the number of credits issued. However, no outcome measures were available at the time of writing (Box 4).

Figure 11. Estimated outputs of public spending on housing by end of programme

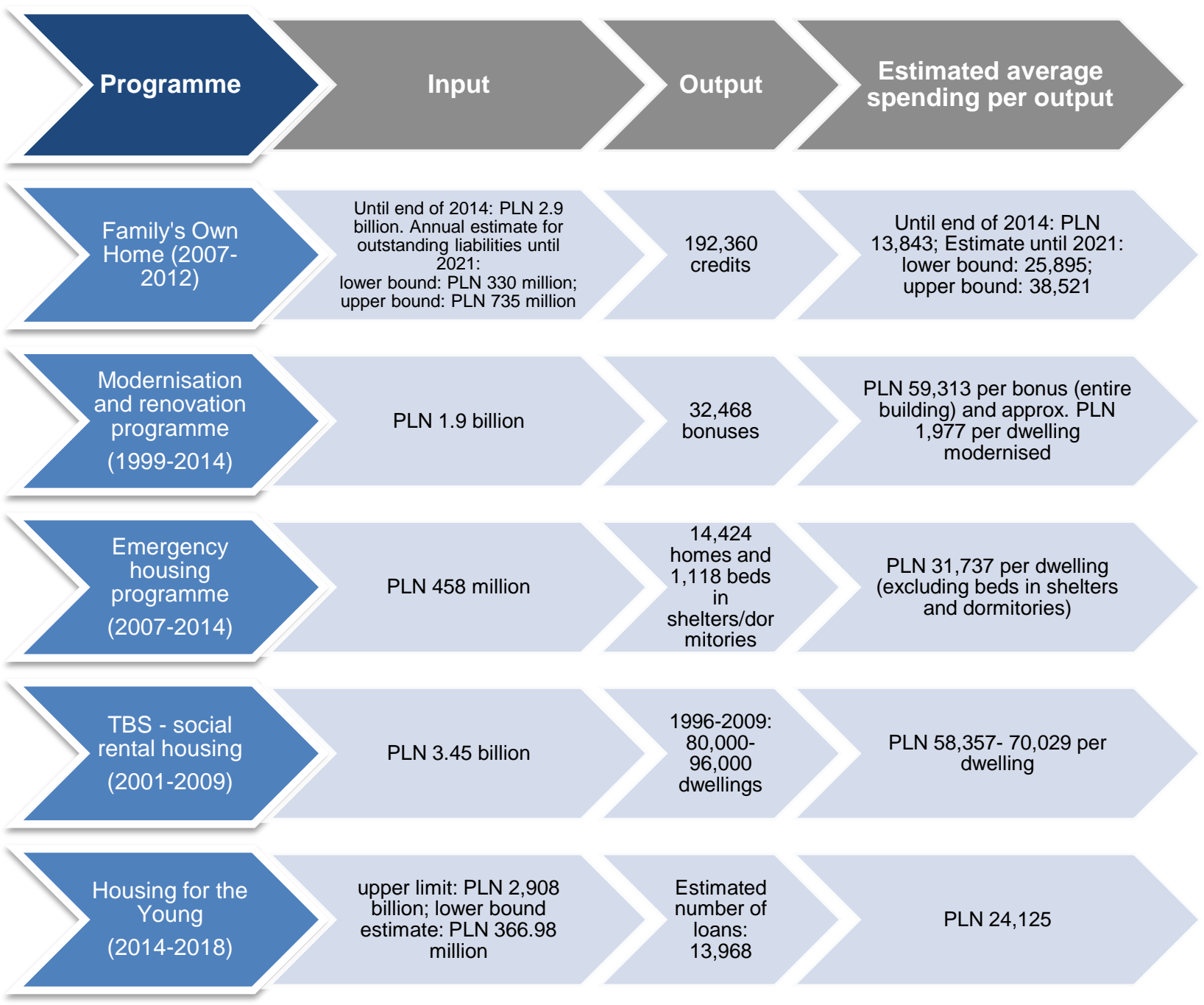

Notes: Numbers represent estimated averages (money spent/output (dwellings build or loan take up). In case of loan take up, it is implicitly assumed that 1 loan equals 1 dwelling. All monetary values are calculated using constant prices of 2010 using the OECD harmonized consumer price index (OECD.Stat - Consumer prices MEI), for estimations beyond 2014, no further inflation was assumed. Further assumptions: The programme Families own home has outstanding liabilities until 2021. Only numbers until 2015 were provided, so two scenarios were assumed: lower bound, for the years 2016-2012, the national government expenditure will be the same as in 2015 (PLN 330 million), upper bound: for the years 2016-2018 the highest value reported (in 2013) will be used for each year. The true value is likely to lie between these two bounds. Dwelling for the young: No official numbers were available so far, but the program is financed by special budget reserve, which cannot exceed (in current prices) PLN 600 million in 2014, PLN 715 million in 2015, PLN 730 million in 2016, PLN 746 million in 2017 and PLN 762 million in 2018. Estimated numbers reported here are based on estimates from the Ministry of Infrastructure and Development. In 2014, 9145 loans were granted within this program, and associated costs were PLN 208 million, or PLN 22.745 per loan (in current prices). While the TBS programme started in 1996, only spending per year from 2001 onwards was provided. The estimated average takes the differences in years into account. $\left({ }^{*}\right)$ Emergency housing programme is financed through public resources: $30-50 \%$ from the national government and the remainder from municipal authorities.

Source: OECD elaboration based on data provided by the Ministry of Finance.

Considering first the number of outputs generated by each instrument (e.g. housing credits issued, dwellings rented), Family's Own Home appears to have resulted in the largest number of total outputs over 
the course of the programme. Between 2007 and 2013, just over 192000 preferential loans were registered, the highest output among the programmes assessed in Figure 11. However, such an assessment assumes that each loan taken up results in a new home, which has not necessarily been shown to be the case. As mentioned previously, Herbst (2012) finds that a large share of the credits were used by households to refinance existing credits rather than build new homes. Moreover, Radzimski (2014) finds that the number of housing permits actually decreased during the period of policy implementation.

In terms of the estimated spending per output, the final column in Figure 11 provides a very preliminary sense of the efficiency of each housing initiative. At just under PLN 2000 (in 2010 prices) per dwelling modernised, the modernisation programme appears to be an efficient instrument. It should also be emphasised that this simple input-output measure does not account for the wider benefits of the programme; for instance, long-term savings due to more energy efficient housing are neglected (see Box 5). The Family's Own Home programme might appear to be relatively efficient if one considers only the resources that have been allocated to-date; however, the majority of liabilities are still outstanding and will affect the national budget until 2021. To account for this, lower and upper bound estimates have been calculated, though these estimates remain highly preliminary. Based on these supplementary estimates, the estimated cost per output is closer to the range of costs for the other instruments assessed in the above Figure.

Between 2001 and 2009, about PLN 3.45 billion (2010 prices) were allocated to the TBS programme for social rental housing, which was subsidised by resources from the national budget between 1995 and 2009; this input corresponds to about 96000 dwellings constructed during this period. Estimates based on the preliminary information for the most recently introduced programme, Housing for the Young, suggest that the new programme may be an improvement on Family's Own Home in terms of lower estimated spending per dwelling and its more limited long-term implications for the budget (a one-time subsidy). 


\section{Box 5. The Polish modernisation fund}

The support of modernisation and renovation programme provides financial support from the national budget in the form of subsidies that aim to increase the quality of the existing housing stock. Established in 1998, it is the longest-running of the currently active national government spending programmes for housing; moreover, it is also notable in its provision of clear policy objectives and results that are monitored and evaluated.

For the first ten years, it was defined as a modernisation bonus for investors (legal persons, local authorities, natural persons and housing associations) implementing projects that significantly reduce the energy consumption of residential buildings, collective accommodation buildings and buildings owned by territorial self-government units (e.g. for the heating and hot water supply, this would be achieved by modernising the heating system, improving heat insulation, replacing windows and making other building improvements). In 2009, the programme introduced the possibility of obtaining a renovation bonus on account of implementing a renovation project in a multi-family building that had been developed prior to 1961 (as these buildings tend to be in the worst technical condition with the lowest equipment standards). However, bonuses for modernisation projects continue to dominate within this programme. Between 2009 and 2012, about 12000 modernisation projects were supported, compared to only about 1000 renovation projects.

The modernisation bonus constitutes a repayment of $20 \%$ of a loan drawn by an investor for project execution, however it cannot exceed $16 \%$ of the total costs of undertaking (or the double amount of expected annual energy savings), as determined in the energy audit. To be eligible for the bonus, the minimum calculated energy savings after the refurbishment should exceed $25 \%$ per year. Furthermore, the energy audit, a document containing information on technical assumptions for the refurbishment, estimates of the costs and their effectiveness, monthly rate of repayment of the loan, required own sources and the amount of the loan are fundamental. The energy audits themselves are subject to verification by the Bank Gospodarstwa Krajowego (BGK, National Development Bank). Ex-post, commercial banks that provided the loan as well as representatives of the Ministry of Infrastructure and Development or the BGK verify the final result of modernisation. The result in terms of savings is indirectly reported to the Ministry of Environment through a decrease in the demand and the type of fuel. The budget subsidies of PLN 1.5 billion between 1999 and 2013 generated energy savings of about PLN 750 million during that period.

\section{Number of applications and premiums granted} in 1999-2014

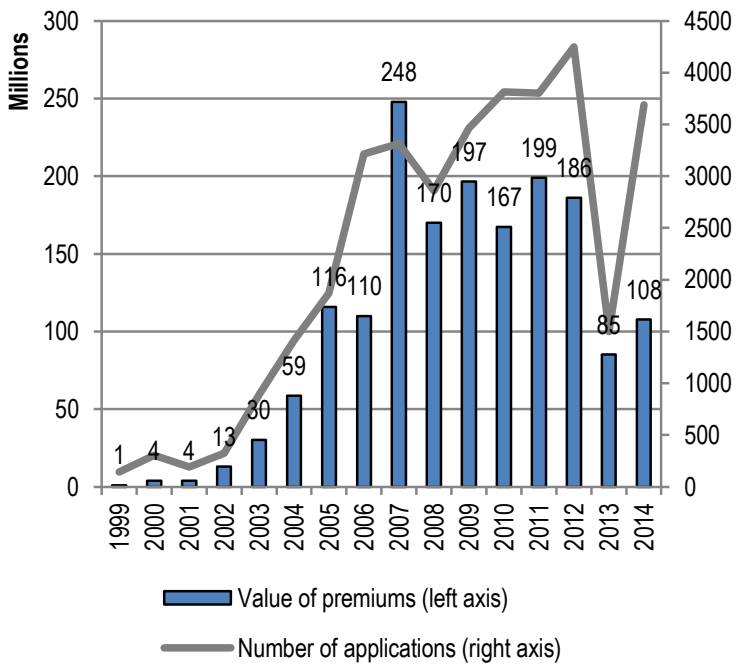

Savings in energy costs due to thermomodernization undertakings in PLN millions (accrual basis)

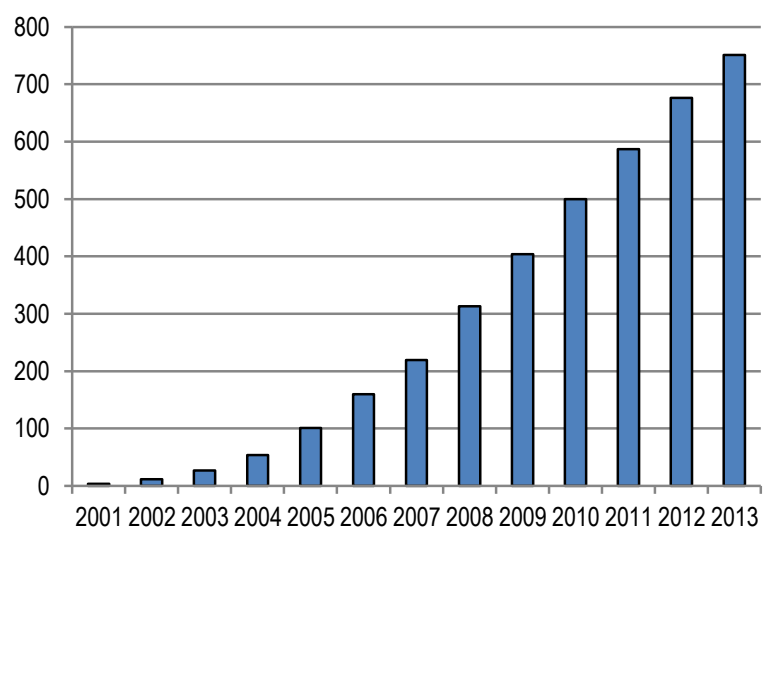

Source: National Development Bank (Bank Gospodarstwa Krajewo, BGK) (2015) (2015), https://www.en.bgk.pl/activities/governmenttarget-funds/thermomodernization-fund/, (accessed May 2015); Rekiel, M. (2015), "Thermal modernisation Fund in Poland"; presentation made to the OECD in January 2015. 
It should be kept in mind, however, that an assessment based on the average expenditure per dwelling is not a satisfactory result, depending on the objective the respective policy targets. Thus, if the objective is to decrease the housing deficit, the pure accumulation of new homes might seem satisfactory. However, as shown above, the housing gap today is more one of affordability. Therefore, as has been discussed, it would seem important that housing policies provide sufficient housing opportunities for lower income households.

\section{Possible directions for Poland}

To establish a simple measurement system to monitor the progress and effectiveness of each policy intervention, policy makers should build on existing indicators and available data. General considerations for designing indicators are summarised in Box 6.

\section{Box 6. Considerations for designing indicators}

Indicators are always tailored to the outcome of the policy that they are supposed to monitor. Therefore, their quality can only be judged in the context of specific policy objectives. Nevertheless, there are some general considerations that should be taken into account when devising indicators:

- Avoid using output measures for outcome indicators. The previous section has shown the difference between output and outcome indicators and has argued that both types of indicators have their justification. However, their use needs to match their respective purpose. Outcomes should always be measured by outcome indicators and outputs by output indicators. Although this sounds obvious, one of the most common mistakes in devising indicators is the use of an output measure for an outcome indicator. Therefore, the careful verification that a proposed outcome indicator actually represents an outcome measure and not just an output is an essential part in the development process of an indicator.

- Match the indicator to the objective and ensure it is responsive to policy. Indicators need to be wellaligned with objectives in the sense that the outcome that is measured by the indicator is the outcome that a policy is aiming to achieve. In other words, the indicator should measure an outcome that can be reasonably expected to be affected by a well-designed policy. As most policy objectives are complex and often only partially quantifiable, it is normal that there are discrepancies between the outcomes of policy objectives and the outcomes measured by indicators. However, if the differences become too large, there is a risk that an indicator measures an outcome that is not responsive to the policy in question. Such an indicator would be ineffectual for monitoring and should therefore be discarded. In order to find the appropriate indicator for an objective, the hierarchical maps of policy objectives described earlier and programme logic models are helpful tools. They can clarify how objectives and policies are related to outcomes and indicators.

- Focus on a limited number of indicators. Streamlining well-being information into a clear set of concrete policy messages is essential for the success of a measurement initiative. Some experiences suggest that an oversupply of information can obstruct understanding. A proliferation of measurement initiatives led by different bodies can result in a plethora of indicators at different spatial scales and time lines, which only adds to complexity. Better co-ordination of measurement initiatives could promote knowledge spillovers, reduce the cost of producing comparable information and pool resources for generating indicators that are not available from official sources. 


\section{Box 6. Considerations for designing indicators (continued)}

- Identify baselines and targets. The availability of baseline data is a critical precondition for evaluating policies. A baseline is defined as the value of a result indicator at the beginning of the programming period, before a given policy is put into effect (for example, the share of households paying more than $30 \%$ of household income on housing). However, it is often difficult to pinpoint a realistic baseline in practice. It may be readily available in statistical or administrative data, but in some cases (typically in the case of subjective perception indicators), a baseline must be generated, for example by surveys. Similarly, identifying targets introduces powerful impetus for encouraging improvement, but this remains a challenging exercise and must be robust to inform policy decisions effectively. While an ideal measurement cycle would involve choosing a target within a determined time horizon, the characteristics of the policy cycle make it difficult to identify when results will be detectable. Typically, results might materialise only after the specific policy cycle has been completed. Setting precise values to be achieved for each indicator requires, at a minimum, an overall assessment of the current situation and of the feasibility of the objectives, the involvement of the scientific community and extensive consultation with citizens and other stakeholders from civil society (see OECD (2014c), How's Life in Your Region?).

- Keep indicators consistent over time. Monitoring developments over time is a central function of indicators. Looking at an indicator for a single time period can provide valuable information, but the full potential of indicators is realised only by analysing how they develop over time. In order to ensure that consecutive readings of an indicator are comparable, changes in the definition of indicators should be avoided whenever possible. The need to change the definition of indicators can be reduced by considering two aspects when devising them: indicators should (i) be based on data that is available in regular time intervals and (ii) refer to an outcome that remains relevant for the foreseeable future.

- Use data that becomes available without long time lags. A central function of indicators is to provide continuous and timely feedback to policy makers. To be able to accomplish this task, indicators need to be based on data that becomes available quickly and at a sufficiently high frequency. When judging the quality of potential indicators, the timeliness with which they become available should always be considered. The quicker information becomes available, the faster policy makers can react to it.

- $\quad$ Normalise indicators with appropriate denominators. Indicators are supposed to provide policy makers and the public with easily accessible and meaningful overviews of the conditions in different policy fields. Therefore, indicators should convey as much information as possible in a single number. Furthermore, as little additional information as possible should be required for their interpretation. This implies that indicators should be normalised with suitable denominators. Normalisation in this context refers to the division of the actual outcome variable by another variable. Usually, the aim is to express the indicator per unit of another variable or as share of a larger category. Typical examples of such normalised indicators are "dwellings per 1000 residents", "the share of the population experiencing overcrowding", etc. All these indicators have in common that the outcome could be expressed in nonnormalised terms, but for various reasons it is desirable to present them as mentioned above.

- Minimise the cost of data collection. The administrative burden and costs related to collecting and processing relevant data can be significant. They should always be kept as low as possible and be justified by the desired use of the indicator. Whenever possible without sacrificing the quality of an indicator, existing data sources should be used for it. For instance, policy-relevant information is often already available from statistical or administrative sources, and has tremendous potential to create value for the society as a whole When embarking on developing metrics, national and subnational governments may thus not need to start from scratch and generate completely new data, but start by reviewing the extent of existing data and seeking access to it. For example, in the United States, the Partnership for Sustainable Communities carried out a scan of existing indicators used by cities and regions to monitor sustainable development. It found more than 300 indicators for measuring transport, land use and housing outcomes that could be reused and adapted to the needs of specific communities. Such data are sometimes freely accessible, whereas in other cases, they need to be deliberately sought out. 


\section{Box 6. Considerations for designing indicators (continued)}

If an indicator requires new data collection, it needs to be weighed against the potential gain in quality due to the new data justifies the costs of collecting it. If the information gain from a new indicator is small or the collection of data very costly, it might even be reasonable to forego the use of an indicator completely. In this context, it is important to consider not only the costs for the public administration, but also the costs imposed on the private sector and civil society. Data collection and other information provision requirements create significant costs for businesses. Whenever possible, governments should aim at reducing this burden in order to foster private sector activity.

Source : Schumann, A. (2016), "Using Outcome Indicators to Improve Policies: Methods, Design Strategies and Implementation", OECD Regional Development Working Papers, 2016/02, OECD Publishing, Paris. http://dx.doi.org/10.1787/5jm5cgr8j532-en; OECD (2014c), How's Life in Your Region?: Measuring Regional and Local Wellbeing for Policy Making, OECD Publishing, Paris. DOI: http://dx.doi.org/10.1787/9789264217416-en.

While it is important to continue to expand the selection of indicators over time, changes to the definition of indicators should nevertheless be avoided to allow for a consistent interpretation over time. While looking at an indicator for a single time period can provide valuable information, the full potential of indicators is usually realised by analysing how they develop over time. For example, in Australia, the Measures of Australia's Progress provide a summary of information on areas of life that Australians reported as important for national progress. The "Scotland Performs" initiative includes a user-friendly feature that indicates the evolution of performance in each indicator, using a directional arrow - up, down or horizontal - to signal improvement, decline or no change (Box 7). Thus, a consistent definition of indicators over time should be pursued. The need to change the definition of indicators can be reduced by considering two aspects when devising them: i) indicators should be based on data that is available in regular time intervals and ii) they should refer to an outcome that remains relevant for the foreseeable future.

\section{Box 7. The "Scotland Performs" initiative}

When the new government of Scotland took office in May 2007, it set out to streamline government resources and improve overall territorial performance. To do so, it aligned the government around five strategic objectives - a wealthier and fairer, smarter, healthier, safer and stronger, and greener Scotland. From these five objectives, it established a series of 16 national outcomes articulating what Scotland wished to achieve over the subsequent 10 years. It then established a set of 50 indicators that cut across many of the national outcomes, helping decision makers and policy designers identify policy complementarities, and helping citizens identify where progress can be made in more than one area. For instance, one national outcome is stated as: "Our young people are successful learners, confident individuals, effective contributors and responsible citizens". This is related to three strategic objectives: smarter, healthier, wealthier and fairer; and has 15 associated qualitative and quantitative indicators. These are primarily outcome oriented, and range from improving people's perception of their neighbourhood to reducing deprivation among children. On its website, the government has taken care to communicate its strategic objectives. It explains why each national outcome is important, the factors that can influence them and the role of the government in achieving them. It also identifies the related strategic objectives and relevant national indicators. 
Box 7. The "Scotland Performs" initiative (continued)

Performance in each indicator is easy to interpret, as it is based on an arrow - up, down or horizontal - to indicate improvement, decline or no change over time. The importance of each indicator is also explained on the website, as well as its current status, the indicator measure, what influences change, the government's role, how Scotland is performing in the indicator over time (graphic representation), criteria for change, partners engaged in creating change and any other related strategic objectives. These latter two points highlight not only the different stakeholders engaged, but also the multi-dimensionality and complementarity of well-being and taking an integrated approach to policy making.

Scotland constantly monitors its performance and updates its goals accordingly. For example, a national outcome relating to older people was added in 2011 . The set of indicators is also adjusted when necessary, and the original 45 indicators in 2007 have increased to 50 in 2014. Some remain untouched, and the definitions of others have been modified. Twelve were added in 2011, and seven were either removed, since they related to targets that were already achieved, or were replaced by more appropriate measures of progress.

Source: Scottish Government (2014), "Scotland Performs", www.scotland.gov.uk/About/Performance/scotPerforms (accessed on 4 July 2014).

Possible indicators of housing policy instruments that could be considered by policy makers in Poland are summarised in Table 7 . These could include information on tenure structure, housing affordability (e.g. housing expenditure as share of income and housing costs overburden rates), housing quality (e.g. overcrowding, availability of basic facilities, severe housing deprivation), household demographic characteristics and trends, and/or social policies for housing (spending on housing policy instruments). Moreover, each indicator should be accompanied by background information that allows for appropriate interpretation (Box 8). 
Table 7. Possible indicators for housing policy instruments

\begin{tabular}{|c|c|c|}
\hline \multirow{2}{*}{$\begin{array}{l}\text { Affordable housing } \\
\text { policy goals }\end{array}$} & \multicolumn{2}{|c|}{ Indicators } \\
\hline & Outputs & Outcomes \\
\hline $\begin{array}{l}\text { Preserve and expand the supply of } \\
\text { quality housing }\end{array}$ & $\begin{array}{l}\text { - \# of units built or rehabilitated } \\
\text { - } \quad \text { \# of units improved or upgraded } \\
\text { - Share of new units affordable } \\
\text { for very-low, low and moderate- } \\
\text { income households }\end{array}$ & $\begin{array}{l}\text { - \# of units affordable for very } \\
\text { low, low and moderate income } \\
\text { households } \\
\text { - \# of physically deficient units } \\
\text { - } \quad \text { \# of overcrowded units } \\
\text { - \# of households on the waiting } \\
\text { list for social housing units }\end{array}$ \\
\hline $\begin{array}{l}\text { Make housing affordable and more } \\
\text { readily available }\end{array}$ & $\begin{array}{l}\text { - } \quad \text { \# of housing vouchers issued } \\
\text { - Share of available vouchers } \\
\text { utilised } \\
\text { - } \quad \text { of households relocating with } \\
\text { housing search assistance }\end{array}$ & $\begin{array}{l}\text { - \# of very low, low and } \\
\text { moderate income households } \\
\text { paying }>30 \% \text { of income on } \\
\text { housing } \\
\text { - \# of very low, low and } \\
\text { moderate income households } \\
\text { paying }>50 \% \text { of income on } \\
\text { housing }\end{array}$ \\
\hline $\begin{array}{l}\text { Promote socio-economic diversity in } \\
\text { residential neighbourhoods }\end{array}$ & $\begin{array}{l}\text { - Index of residential segregation } \\
\text { by income level }\end{array}$ & $\begin{array}{l}\text { - Share of new social housing } \\
\text { dwellings in low-poverty } \\
\text { neighbourhoods } \\
\text { - Share of housing benefit } \\
\text { recipients moving to low- } \\
\text { poverty neighbourhoods } \\
\text { - Socio-economic mix of } \\
\text { assisted developments }\end{array}$ \\
\hline $\begin{array}{l}\text { Promote balanced metropolitan } \\
\text { growth }\end{array}$ & $\begin{array}{l}\text { - Share of new affordable housing } \\
\text { in suburban areas } \\
\text { - Volume of residential } \\
\text { investment in older, centre-city } \\
\text { areas }\end{array}$ & $\begin{array}{l}\text { - Geographic concentration of } \\
\text { affordable housing } \\
\text { - Average commute times, by } \\
\text { jurisdiction } \\
\text { - Ratio of jobs to dwellings, by } \\
\text { jurisdiction }\end{array}$ \\
\hline
\end{tabular}

Source: Adapted from Katz et al (2003), "Rethinking Local Affordable Housing Strategies: Lessons from 70 Years of Policy and Practice", Discussion paper prepared by the Brookings Institution Center on Urban and Metropolitan Policy and the Urban Institute.

By extension, it is also important for policy makers to conduct ex-post policy evaluation to avoid repeating mistakes and learn from successes. Policy monitoring provides valuable feedback to policy makers, but it cannot give a definitive answer regarding the effectiveness of a policy. In order to do so, different approaches are required that are commonly summarised under the label policy evaluation. Policy evaluation is usually based on statistical and econometric techniques that distinguish the impact of a policy from confounding factors, but in some cases interpretative techniques such as focus groups can also be employed. Policy evaluation has typically higher data requirements than policy monitoring and often requires that policies are designed in specific ways that allow them to be evaluated. Ideally, monitoring and evaluation should complement each other. Monitoring is supposed to provide a continuous feedback that shows strengths and weaknesses within policy fields and enables policy makers to react quickly to them. In contrast, the high analytical requirements of policy evaluation imply that it can only be done infrequently and with long time lags. However, a properly conducted policy evaluation can provide a higher certainty about the effectiveness of a policy than monitoring by indicators (Schumann, 2016). 


\section{Box 8. Example of background information for an indicator}

This box provides a hypothetical example of the background information that could be provided with every indicator. Depending on the intended audience, some aspects could be elaborated in more detail, whereas others could be omitted. For example, if the background information was primarily intended for the general public, more emphasis could be put on why the outcome is important. If it was primarily intended for experts, more information regarding the data collection methods could be provided.

Indicator: Indicator A1: Share of dwellings affordable for very low, low and moderate income households

Corresponding policy objective: Objective A: Expand the supply of affordable housing for very low, low and moderate income households.

Current value / target value: $25 \% / 40 \%$ by 2020 .

Development over the past three years: $\pi(+1.4$ percentage points)

Unit of measurement: Percent of very low, low and moderate income households who pay less than $30 \%$ of their household income on housing costs.

Outcome contributes to: Objective B: Reducing the share of households living in overcrowded or otherwise substandard conditions.

Outcome is influenced by: Objective D: Increasing the share of the rental housing stock.

Why is it important to measure the outcome: Affordable housing not only fulfils a basic human need for shelter, it also contributes to greater well-being for individuals and households, can generate more consumer spending on other items, and can be an important factor in attracting economic activities (workers and jobs) to a given area.

Caveats/limits: The indicator is based on a representative sample of 5000 households from 5 regions.

Source: adapted from Schumann, A. (2016), "Using Outcome Indicators to Improve Policies: Methods, Design Strategies and Implementation", OECD Regional Development Working Papers, 2016/02, OECD Publishing, Paris. http://dx.doi.org/10.1787/5jm5cgr8j532-en.

\section{5) To what extent are housing policies coherent with other policy objectives?}

\section{Rationale}

Policy makers should also take care to consider the entire range of housing policies to ensure coherence among different policy interventions (e.g. policies to support home ownership vs. those to expand the rental supply; subsidies, credits, vouchers or regulatory reforms; supply-side vs. demand-side measures). This comprehensive review of all housing interventions should identify how each policy can meet its objectives and possibly contribute to support, rather than contradict, other objectives.

It is also important to consider the potential effects beyond the housing sector to identify whether there are contradictory policies from other sectors and/or other levels of government. Most policies do not work in isolation. Their effectiveness generally relies on conditions in areas that are not directly related to them, and apparently unrelated policies can be crucial for the success or failure of a policy. These so-called complementarities present important opportunities, but also challenges to policy makers. In the best case, 
policies that address complementary policy fields simultaneously can create virtuous cycles, in which progress in one field leads to progress in another field and vice versa. In the worst case, a well-designed policy can be rendered ineffectual by the lack of a complementarity.

\section{Assessment of the situation in Poland}

A comprehensive review of the entire range of housing policies and their potential implications on other policy domains does not appear to have been systematically conducted in Poland to-date. While the following examples are not exhaustive, they are illustrative of the potentially unintended effects of housing policies: limiting labour mobility; exacerbating urban sprawl; and contributing to regional inequalities. These three themes will be discussed briefly.

First, as discussed, Poland's housing market is dominated by owner-occupied homes. Most housing interventions have tended to support home ownership; new initiatives to support rental housing are under development by both the national government and the National Development Bank (BGK). Such a high ownership rate implies an underdeveloped rental market, which in turn could affect residential and labour mobility. In 2007, just $2.1 \%$ of households changed residence, the second-lowest value among OECD countries, after Slovenia (1.8\%) (Figure 12, Box 9) (Nickell and Layard, 1999; see e.g. Oswald, 1996; Sánchez and Andrews, 2011).

\section{Figure 12. Residential and labour mobility / long-term unemployment}

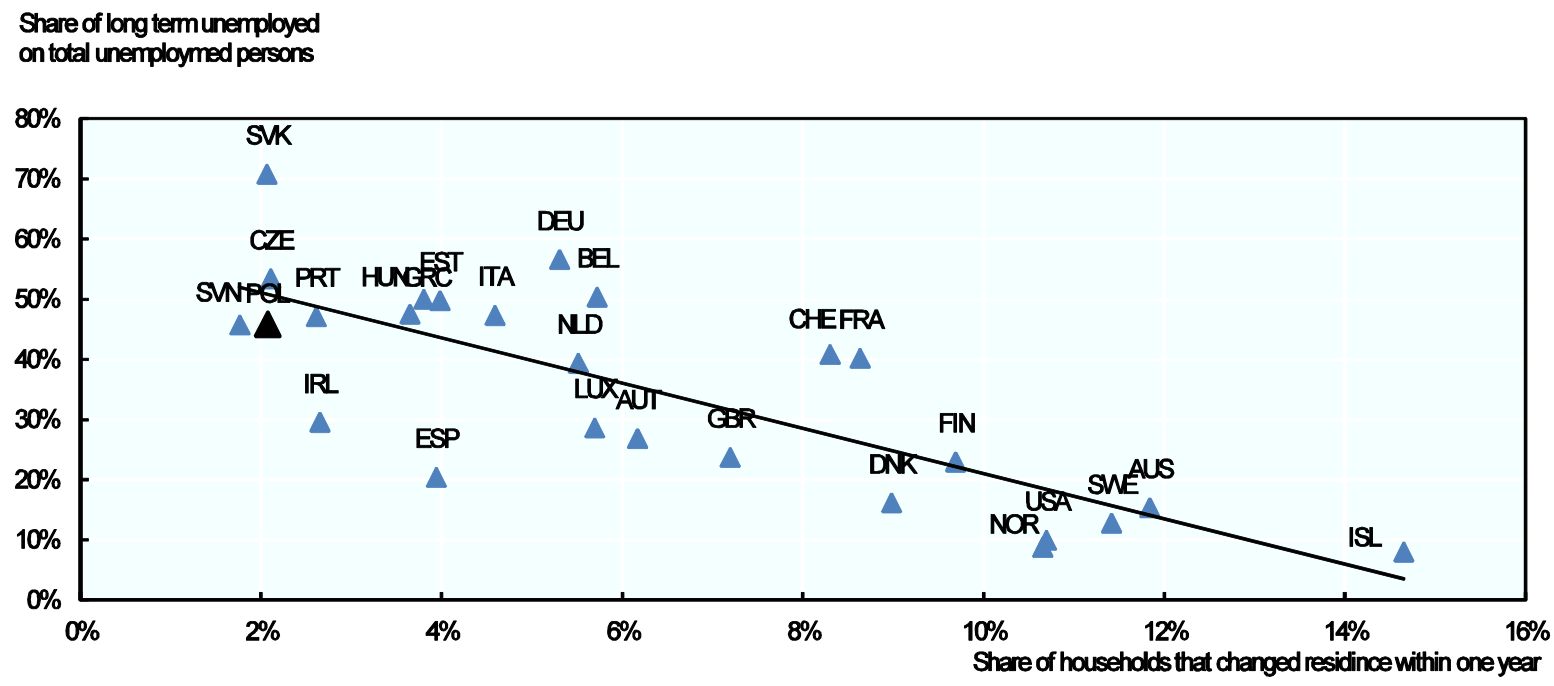

Note: Long term unemployment is defined as 1 year or more.

Source: OECD (2011b), "Housing and the Economy: Policies for Renovation", in OECD, Economic Policy Reforms 2011: Going for Growth, OECD Publishing, Paris. DOI: http://dx.doi.org/10.1787/growth-2011-46-en; OECD (2014d), "Long-term unemployment rate" (indicator), http://dx.doi.org/10.1787/76471ad5-en. 


\section{Box 9. The importance of residential mobility for the labour market}

Residential and geographical mobility contribute to the efficient matching of jobs and the allocation of human resources within the labour market (Henley et al., 1994), especially in the event of permanent shocks requiring a reallocation of production factors - such as sector and structural changes related to globalisation or technological progress (Janiak and Wasmer, 2008). For instance, studies have shown that in the United States adjustment to shocks largely occurs through migration between regions (see e.g. Blanchard and Katz, 1992; Decressin and Fatás, 1995). Indeed, there is a positive correlation across countries between residential mobility and reallocation of workers. Policy interventions in housing markets may affect labour mobility and could give rise to mismatches and other inefficiencies in these markets (see e.g. Van der Vlist et al., 2002).

Macro studies across countries or regions suggest that high homeownership is associated with low residential mobility and high unemployment (Blanchflower and Oswald, 2013; see Oswald, 1996). Micro-data, on the other hand, tend to indicate that owning a home makes people more likely to be employed than when renting, thereby pointing at a positive effect at the individual level. Some research indicates that the contradictory findings can be explained by homeowners - especially those who have to pay off their mortgage - who are likely to accept lower wages in order to take up employment in the region. This effect is enforced when transaction costs of selling a house are high. Thus, once a region faces an economic downturn followed by large unemployment - a trend that is present in some regions in Poland - homeowners experience for one a lower likelihood to find a local job even when they are willing to accept wage cuts (Coulson and Fisher, 2009; Head and Lloyd-Ellis, 2012; see e.g. Munch et al., 2006). Second, homeowners may be constrained in their geographical mobility as they have negative home equity or because they anticipate serious difficulties in selling their current home (Chan, 2001; Karahan and Rhee, 2013). To identify the exact channels and the relative importance of tenure choice on labour market mobility and outcome further research is needed.

Sources: Henley, A., R. Disney and A. Carruth (1994), "Job tenure and asset holdings", Economic Journal, Vol. 104; Janiak, A. and E. Wasmer (2008), "Mobility in Europe - Why it is low, the bottlenecks and policy solutions", European Economy, Economic Papers, No. 340, Directorate-General for Economic and Financial Affairs, European Commission, Brussels, September, available at: http://ec.europa.eu/economy finance/publications/publication13173 en.pdf; Decressin, J. and A. Fatas (1995), "Regional Labor Market Dynamics in Europe", European Economic Review, Vol. 39; Blanchard, O. and L.F. Katz (1992), "Regional evolutions", Brookings Papers on Economic Activity, No. 1; Van der Vlist, A. et al. (2002), "Residential mobility and local housing market differences", Tinbergen Institute Discussion Paper, TI 2002-003/3; Oswald, A.J., (1996), A Conjecture on the Explanation for High Unemployment in the Industrialized Nations: Part I, The Warwick Economics Research Paper Series (TWERPS), University of Warwick, Department of Economics; Blanchflower and Oswald (2013), "Does high home-ownership impair the labor market?" NBER Working Paper No. 19079; Munch, J.R, Rosholm, M., Svarer,M. (2006). Are Homeowners Really More Unemployed? The Economic Journal, Volume 116, Issue 514, p991-1013; Head, Allen, and Huw Lloyd-Ellis (2012), "Housing liquidity, mobility and the labour market." The Review of Economic Studies; Coulson, N. Edward, and Lynn M. Fisher (2009), "Housing tenure and labor market impacts: The search goes on." Journal of Urban Economics 65(3): 252-264. Chan, S.(2001), "Spatial lock-in: Do falling house prices constrain residential mobility?", Journal of Urban Economics, Vol. 49, No. 1; Karahan, F. and S. Rhee (2013), "Geographical reallocation and unemployment during the Great Recession: The role of the housing bust", Federal Reserve Bank New York.

Second, housing policies promoting ownership may contribute to urban sprawl, thereby increasing the cost for municipalities to provide infrastructure and communal services connected to housing. Housing policies that promote home ownership and increase construction can ultimately result in sprawling urban areas, as land tends to be more available and cheaper in the suburban area. This pattern is enforced when the eligibility of housing programmes are subject to a maximum price per square meter. When set too low, construction of housing that meets the criteria is only affordable where land is cheap. Indeed, there is anecdotal evidence that the Family's Own Home programme, due to the maximum ceiling on the construction cost of new homes, housing has been disproportionately concentrated in peripheral areas where land is cheaper, thereby exacerbating urban sprawl. ${ }^{7}$

7. Based on discussions between the OECD and the staff of the Ministry of Infrastructure and Development during the study mission to Poland in February, 2015. 
As local governments are responsible for providing infrastructure and basic services connected to housing, urban sprawl can generate higher costs for municipalities. These higher costs could be avoided through incentives to encourage housing development in desirable (e.g. central) areas, as well as better urban and land-use planning at the local level. Indeed, looking at recent changes in population density, most metropolitan areas in Poland have experienced a decreasing population density in the urban core, and an increasing population density in the commuting zone (Figure 13).

Figure 13. Change in population density in Polish metropolitan areas
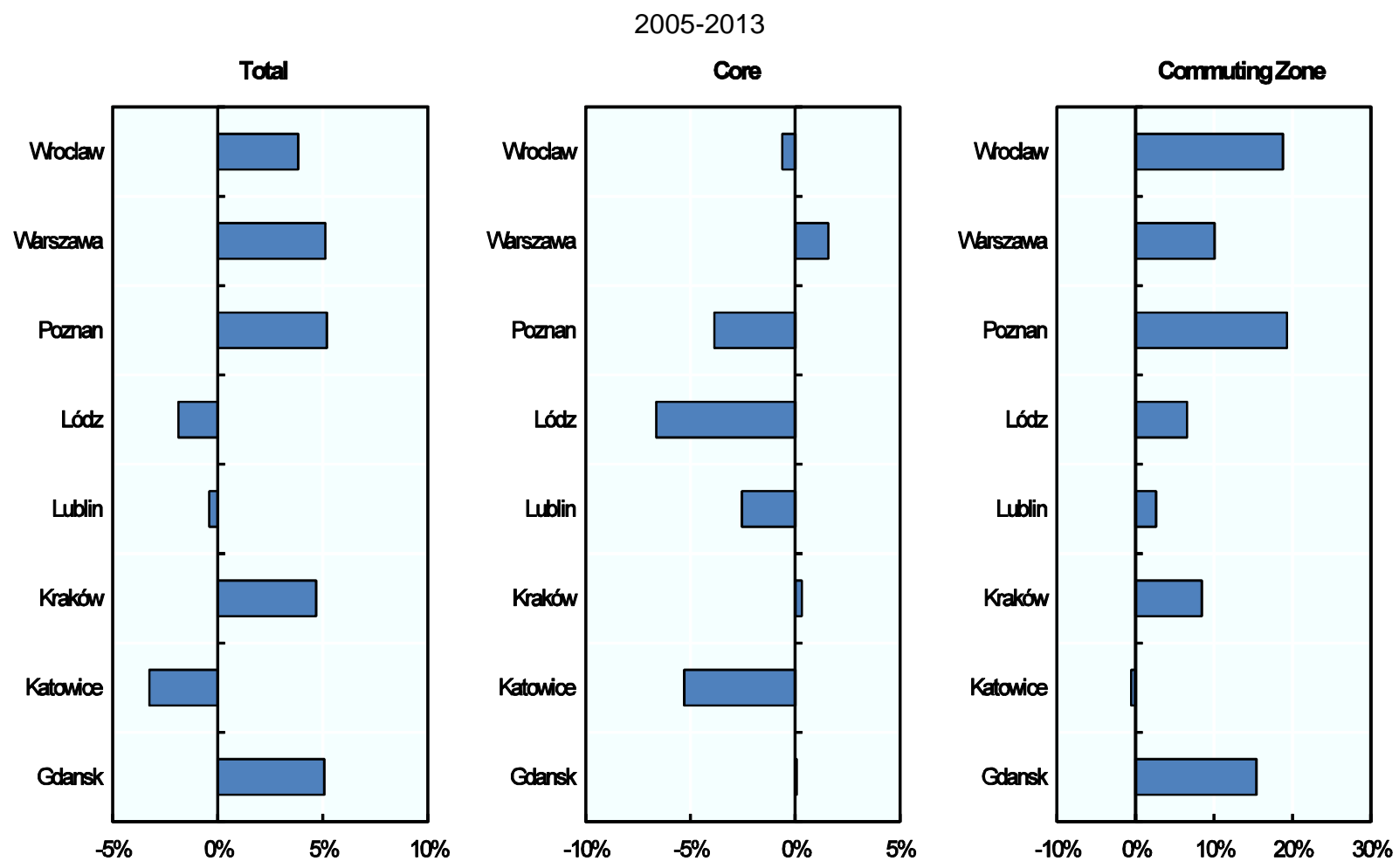

Source: OECD (2013b), "Metropolitan areas", OECD Regional Statistics (database), http://dx.doi.org/10.1787/data-00531-en; (accessed 30 March 2015).

Third, the design of housing policies can also have important consequences for regional inequalities. Municipalities, responsible for social housing, tend to struggle with the significant financial burden imposed by the current system of housing allowances. This burden is especially high for municipalities that have a higher share of low-income households and a high share of unemployment, as a large share of local financial resources come from income tax. Combined with high ownership rates and low residential mobility, these conditions could in fact exacerbate regional inequalities, thereby imposing additional expenses for the national budget in the future.

Moreover, regional inequalities may also be reinforced by the current design of national funds through the emergency housing programmes. Although not the intention, some municipalities use funds from the national government intended to develop emergency housing (e.g. for the very poor, homeless, vulnerable populations) to build new municipal housing (e.g. targeting low- to medium-income households). They then convert the existing, low-quality municipal housing stock into emergency homes. The result of this practice is that municipalities without a large existing municipal housing stock for this transferral are even further limited in their development of all types of housing for very-low and low-income households. 
Using the newly built homes as emergency homes may impose additional financial pressure on those municipalities budget as the revenues are too low to be sustainable.

\section{Possible directions for Poland}

An exemplary assessment of the entire range of housing policies in terms of their potential to achieve policy goals is provided in Table 8. A next step would then be to conduct a comprehensive review of the different housing policy interventions across levels of government, to ensure that these efforts work to support each other, rather than at cross purposes. 
Table 8. Evaluating the potential effects of different housing programmes on policy objectives

\begin{tabular}{|c|c|c|c|c|c|c|}
\hline \multirow{2}{*}{$\begin{array}{l}\text { Policy objective } \\
\text { Preserve and } \\
\text { expand the supply of } \\
\text { quality affordable } \\
\text { housing }\end{array}$} & $\begin{array}{l}\text { Rental housi } \\
\text { Supply-side } \\
\text { production }\end{array}$ & $\begin{array}{l}\text { Ig assistance } \\
\text { Demand-side } \\
\text { vouchers }\end{array}$ & $\begin{array}{l}\text { Supply-side } \\
\text { mortgage credit }\end{array}$ & $\begin{array}{l}\text { ne ownership assista } \\
\text { Demand-side } \\
\text { homebuyers tax } \\
\text { policies and } \\
\text { assistance }\end{array}$ & $\begin{array}{l}\text { Supply-side } \\
\text { production }\end{array}$ & Land use regulations \\
\hline & $\begin{array}{l}\text { Yes: rental stock has } \\
\text { expanded, though } \\
\text { more units need to } \\
\text { be produced }\end{array}$ & $\begin{array}{l}\text { Somewhat: may } \\
\text { encourage landlords } \\
\text { to maintain existing } \\
\text { (poor) housing } \\
\text { conditions }\end{array}$ & $\begin{array}{l}\text { Maybe, but impact is } \\
\text { indirect }\end{array}$ & $\begin{array}{l}\text { Maybe, but impact is } \\
\text { indirect }\end{array}$ & $\begin{array}{l}\text { Yes: primary goal of } \\
\text { these programmes } \\
\text { is to expand the } \\
\text { owner-occupied } \\
\text { housing stock }\end{array}$ & $\begin{array}{l}\text { Mixed: some programmes } \\
\text { expand supply while } \\
\text { others limit new affordable } \\
\text { housing construction }\end{array}$ \\
\hline $\begin{array}{l}\text { Make housing } \\
\text { affordable and more } \\
\text { readily available }\end{array}$ & $\begin{array}{l}\text { Yes: but affordability } \\
\text { depends on size and } \\
\text { duration of subsidies }\end{array}$ & $\begin{array}{l}\text { Yes: primary goal is } \\
\text { affordability; success } \\
\text { depends on } \\
\text { households' ability to } \\
\text { find dwellings }\end{array}$ & $\begin{array}{l}\text { Yes, but impact is } \\
\text { indirect }\end{array}$ & $\begin{array}{l}\text { Yes, enhances } \\
\text { buying power, but } \\
\text { depends on price of } \\
\text { housing stock }\end{array}$ & $\begin{array}{l}\text { Yes, primary goal of } \\
\text { these programmes } \\
\text { is affordability and } \\
\text { access }\end{array}$ & $\begin{array}{l}\text { Maybe: rent control may } \\
\text { moderate rental increases } \\
\text { in tight markets but there } \\
\text { is very mixed evidence on } \\
\text { how desirable such } \\
\text { interventions are on the } \\
\text { affordability of the housing } \\
\text { market more broadly }\end{array}$ \\
\hline $\begin{array}{l}\text { Promote socio- } \\
\text { economic diversity in } \\
\text { residential } \\
\text { neighbourhoods }\end{array}$ & $\begin{array}{l}\text { Rarely: depends on } \\
\text { where new units are } \\
\text { built and who is } \\
\text { eligible to occupy } \\
\text { them }\end{array}$ & $\begin{array}{l}\text { Possibly: if } \\
\text { recipients can find } \\
\text { dwellings in socio- } \\
\text { economically diverse } \\
\text { neighbourhoods }\end{array}$ & $\begin{array}{l}\text { Possibly: depends } \\
\text { on locational } \\
\text { decisions of buyers }\end{array}$ & $\begin{array}{l}\text { Possibly: if } \\
\text { recipients can find } \\
\text { housing in socio- } \\
\text { economically diverse } \\
\text { neighbourhoods }\end{array}$ & $\begin{array}{l}\text { Possibly: depends } \\
\text { on the location of the } \\
\text { units produced and } \\
\text { the local economy }\end{array}$ & $\begin{array}{l}\text { Mixed: some reforms can } \\
\text { expand affordable } \\
\text { housing in affluent } \\
\text { neighbourhoods, while } \\
\text { others can make such } \\
\text { development impossible }\end{array}$ \\
\hline Strengthen families & $\begin{array}{l}\text { Possibly: more } \\
\text { research is needed }\end{array}$ & $\begin{array}{l}\text { Possibly: but less } \\
\text { impact if dwellings } \\
\text { are located in } \\
\text { distressed } \\
\text { neighbourhoods }\end{array}$ & $\begin{array}{l}\text { Yes: but less impact } \\
\text { if dwellings are } \\
\text { located in distressed } \\
\text { neighbourhoods }\end{array}$ & $\begin{array}{l}\text { Yes: but less impact } \\
\text { if dwellings are } \\
\text { located in distressed } \\
\text { neighbourhoods }\end{array}$ & $\begin{array}{l}\text { Yes: but less impact } \\
\text { if dwellings are } \\
\text { located in distressed } \\
\text { neighbourhoods }\end{array}$ & No \\
\hline $\begin{array}{l}\text { Promote balanced } \\
\text { metropolitan growth }\end{array}$ & $\begin{array}{l}\text { Rarely: depends on } \\
\text { where new housing } \\
\text { is built }\end{array}$ & $\begin{array}{l}\text { Possibly: depends } \\
\text { on recipients' ability } \\
\text { to find housing in } \\
\text { suburban areas and } \\
\text { close to job } \\
\text { opportunities }\end{array}$ & $\begin{array}{l}\text { Unclear: depends on } \\
\text { general population's } \\
\text { locational choices }\end{array}$ & $\begin{array}{l}\text { Unlikely: though } \\
\text { possible if recipients } \\
\text { can find housing in } \\
\text { suburban areas } \\
\text { close to job } \\
\text { opportunities }\end{array}$ & $\begin{array}{l}\text { Rarely: the location } \\
\text { of housing in most } \\
\text { places has generally } \\
\text { not promoted } \\
\text { balanced } \\
\text { metropolitan growth }\end{array}$ & $\begin{array}{l}\text { Mixed: zoning and } \\
\text { regulatory reforms can } \\
\text { promote affordable } \\
\text { development in all } \\
\text { jurisdictions, though some } \\
\text { do not }\end{array}$ \\
\hline
\end{tabular}

Source: Katz et al. (2003), "Rethinking Local Affordable Housing Strategies: Lessons from 70 Years of Policy and Practice", Discussion paper prepared by the Brookings Institution Center on Urban and Metropolitan Policy and the Urban Institute. 
Moreover, it is important that policy makers seek a greater balance in the type of housing instruments used between those that will impose long-term financial obligations for the national government versus one-time expenditures. As mentioned earlier in this paper, most spending for programmes in the budget has long-term budgetary implications. A review of the type and length of the financial obligation that will be incurred by each policy intervention should be conducted to ensure a more balanced housing policy package.

Ireland, for example, has developed a "Balanced Scorecard" to assist policy makers in programme evaluation (Box 10), which could be considered by Polish authorities. The Scorecard brings together key evaluation questions relating to programme design and implementation, with special attention to crosscutting elements to ensure that interventions are consistent with other policy objectives in the same domain, as well as in other fields. 


\section{Box 10. Ireland's "Balanced Scorecard" to assist policy makers in evaluating housing expenditures}

Irish authorities introduced a standard report - a so-called "balanced scorecard" - which is based on a number of important criteria that are common to all housing programme evaluations. These criteria include:

\section{Quality of programme design}

- $\quad$ Are the programme objectives clearly specified?

- Are the objectives consistent with stated government priorities? Is there a clear rationale for the policy approach being pursued?

- Are performance indicators in place from the outset, to allow for an assessment of programme success or failure in meeting its objectives? If not, can such success/failure indicators be constructed ex post?

- Have alternative approaches been considered and costed, through cost-benefit analysis or other appropriate methodology?

- $\quad$ Are resources (financial, staffing) clearly specified?

\section{Implementation of programme or intervention}

- To what extent have programme objectives been met? What do the success/failure indicators show?

- Is the programme efficient in terms of maximising output for a given input and is it administered efficiently?

- Have the views of stakeholders been taken into account?

\section{Cross-cutting aspects}

- Is there overlap / duplication with other programmes? Does the programme support other policy objectives?

- What scope exists for an integrated cross-departmental or inter-governmental national/municipal approach?

- $\quad$ Are shared services / e-government channels being used to the fullest extent?

- $\quad$ Can services be delivered more cost-effectively by external service providers?

This approach allows for an overall, standardised quality score to be put in place, providing a programme rating that is of use to policy-makers and to those scrutinising the cost-effectiveness of spending. In other countries, more general programme ratings using the "traffic light" system are found to be useful:

- $\quad$ HIGH Score (Green light) - the programme is well-specified, achieving its objectives, and cost-effective

- INTERMEDIATE Score (Yellow light) - the programme scores highly in some areas, poorly in others: scheme re-design or efficiency improvements must be considered

- LOW Score (Red light) - poor evidence of delivery of objectives; scheme funding should be available for reallocation to other priority areas.

Source : Department of Public Expenditure and Reform (Ireland) (2012), The Public Spending Code, The Public Spending Code:C. Implementation and Post-Implementation. Reviewing and Assessing Expenditure Programmes; available at: http://publicspendingcode.per.gov.ie/reviewing-and-assessing-expenditure-programmes/ (accessed April 2015).

\section{Summary}

This paper analyses direct national public expenditure on housing in Poland, within the context of recent trends in the housing market. Most of national housing programmes operated by the former Ministry of Infrastructure and Development have aimed to address the shortage of housing, which is one of the most critical housing policy challenges in Poland, particularly in urban areas. While Poland has made considerable progress in reducing the housing deficit and improving housing quality, housing affordability 
and limited diversity of the housing stock remain important policy challenges. Thus, the share of households living in overcrowded dwellings and the share of housing of poor quality remain large compared to other European countries, indicating a lack of affordable housing alternatives.

This paper proposes the following strategies to address the housing affordability gap, and especially in a time of fiscal constraints. First, governments - both at the national and local level - might concentrate a larger share of housing assistance to households in greatest need. Based on eligibility criteria, housing instruments in Poland primarily target either the lowest-income households or medium to high-income groups. There is thus a considerable gap in the reach of housing instruments for households that fall in between. A clear understanding of the desired beneficiaries to be targeted by different housing instruments is a critical step in the policy making process. Second, in the context of limited fiscal space for developing strategic housing programmes, it is important that policy makers evaluate a full range of policy options including those that do not imply financial obligations, as well as the "do nothing" alternative. For example, regulatory policies could be reviewed, with the aim of loosening restrictions on the supply of rental housing in Poland. Third, more could be done to generate additional resources for municipal governments to upgrade their housing.

There was insufficient evidence to determine the degree to which specific policies and programmes have contributed to achieving targeted housing policy objectives. Precise, strategic objectives for housing policies overall, as well as for each specific policy instrument, are lacking, resulting in the absence of tools to understand the market failure or policy problem to be addressed. This paper thus recommends more consistent use of indicators, which play a central role in understanding market failures, as well as in the monitoring and evaluation process by generating regular and objective feedback about progress towards policy objectives. In addition, this paper suggests introducing a comprehensive, systematic review of the whole range of housing policy instruments and their potential implications on other policy domains, which has not yet been undertaken. In this sense, it would be important to also consider the potential effects beyond the housing sector to identify whether there are contradictory policies from other sectors and/or other levels of government. Once an appropriate monitoring system is in place, future research could evaluate the effectiveness and efficiency of specific housing policies in Poland. 


\section{Bibliography}

Andrews, D., Caldera Sánchez, A., Johansson, Å. (2011), Housing Markets and Structural Policies in OECD Countries. OECD Economics Department Working Papers, http://dx.doi.org/10.1787/5kgk8t2k9vf3-en.

Andrews, D., Sánchez, A.C. (2011), The Evolution of Homeownership Rates in Selected OECD Countries: Demographic and Public Policy Influences. OECD Journal: Economic Studies 2011, 1-37, http://dx.doi.org/10.1787/eco_studies-2011-5kg0vswapmg2.

Barca, F., McCann, P. (2011), "Methodological Note: Outcome Indicators and Targets - Towards a Performance Oriented EU Cohesion Policy," Brussels.

Blanchard, O.J., Katz, L.F. (1992), "Regional evolutions.” Brookings Papers on Economic Activity, https://www.brookings.edu/wpcontent/uploads/1992/01/1992a_bpea_blanchard_katz_hall_eichengreen.pdf.

Blanchflower, D.G., Oswald, A.J. (2013), Does High Home-Ownership Impair the Labor Market? SSRN Electronic Journal 1 - 49, https://papers.ssrn.com/sol3/papers.cfm?abstract_id=2261951.

Brzeski, W.J., Chiquier, L., Dübel, H.-J., Taffin, C. (2009), "Residential Rental Markets in Poland: TBS Review: Final Report, Advisory Services for the Ministry of Infrastructure," http://bip.transport.gov.pl/pl/bip/programy_i_strategie/budownictwo/reforma_bud_spolecz/px_polan d final report july 1.pdf.

Central Expenditure Evaluation Unit (CEEU) (Ireland) (2010), "Comprehensive Review of Expenditure Thematic Evaluation Series: Social Housing Supports,", http://www.per.gov.ie/en/comprehensivereview-of-expenditure-submissions/ (accessed on February 8, 2016).

Central Statistical Office Poland (2015a), "Industry and Construction, Housing Construction - Dwellings Completed in Residential and Non-Residential Buildings", database, http://stat.gov.pl/bdlen/app/dane_podgrup.dims?p_id=976946\&p_token=0.04433547199163046 (accessed on April 1, 2015).

Central Statistical Office Poland (2015b), "Public Finance - Expenditure of Gminas and Cities with Powiat Status Budgets", database, http://stat.gov.pl/bdlen/app/strona.html?p name=indeks (accessed on April 1, 2015).

Central Statistical Office Poland (2015c), "National Census - Census 2011", database , http://stat.gov.pl/bdlen/app/strona.html?p_name=indeks (accessed on May 20, 2015).

Chan, S. (2001), Spatial Lock-in: Do Falling House Prices Constrain Residential Mobility? Journal of Urban Economics 49, 567-586, http://www.sciencedirect.com/science/article/pii/S0094119000922058.

Coulson, N.E., Fisher, L.M. (2009), Housing Tenure and Labor Market Impacts: The Search Goes on. Journal of Urban Economics 65, 252-264.

Decressin, J., Fatás, A. (1995), Regional Labor Market Dynamics in Europe. European Economic Review $39,1627-1655$. 
Department of Public Expenditure and Reform (Ireland) (2012), “The Public Spending Code, The Public Spending Code: C) Implementation and Post-Implementation. Reviewing and Assessing Expenditure Programmes," http://publicspendingcode.per.gov.ie/reviewing-and-assessingexpenditure-programmes.

European Investment Bank (EIB) (2011), “Jessica Evaluation Study - West Poland: Final Report," www.eib.org/attachments/jessica-poland-west_en.pdf.

Eurostat (2015a), "EU-SILC: Overcrowding Rate by Income Quintile - Total Population", ilc_lvho05q (database) .

Eurostat (2015b), "EU-SILC: Severe Housing Deprivation Rate by Income Quintile”, ilc_mdho06q (database).

Eurostat (2015c), "EU-SILC: Distribution of Population by Tenure Status, Type of Household and Income Group", ilc_lvho02 (database).

Frackowiak, M. (2008), Ekonomiczne I spoleczne problem polskiego mieszkalnictwa [Economic and social problems of housing in Poland], Wydawnictwo PTPN, Poznan.

Head, A., Lloyd-Ellis, H. (2012), Housing Liquidity, Mobility, and the Labour Market. Review of Economic Studies 79, 1559-1589, http://dx.doi.org/10.1093/restud/rds004.

Henley, A., Disney, R., Carruth, A. (1994), Job Tenure and Asset Holdings. Economic Journal 10, 338-49.

Herbst, I. (2012), "W poszukiwaniu polityki mieszkaniowej” [In Search of Housing Policy], http://publica.pl/wp-content/uploads/2012/12/miasta_17.08.pdf.

Janiak, A., Wasmer, E. (2008), Mobility in Europe: Why It Is Low, the Bottlenecks, and the Policy Solutions. European Economy Economic Papers 349, http://ec.europa.eu/economy_finance/publications/publication13173_en.pdf.

Karahan, F., Rhee, S. (2013), "Geographical reallocation and unemployment during the Great Recession: the role of the housing bust," Staff Reports, https://ideas.repec.org/s/fip/fednsr.html.

Katz, B., Turner, M.A., Brown, K.D., Cunningham, M., Sawyer, N. (2003), Rethinking Local Affordable Housing Strategies: Lessons From 70 Years of Policy and Practice, Brookings Institution Center on Urban and Metropolitan Policy and the Urban Institute, Washington, D.C.

Kierzenkowski, R. (2008), "Bridging the Housing Gap in Poland," OECD Economics Department Working Papers, http://dx.doi.org/http://dx.doi.org/10.1787/236314440147.

Ministry of Finance (2015), "Background report prepared for the OECD on the basis of the data of National Statistical Office and the Ministry of Finance; document is not publicly available."

Ministry of Finance (2014), "Annual Report Tax preferences - with estimates for 2009-2011."

Ministry of Housing Territorial Equality and Rural Areas (France) (2015), "Politiques du logement [Housing policies]," www.territoires.gouv.fr/actions-pour-la-relance-de-la-construction.

Ministry of Infrastructure and Development (2010), "Główne problemy, cele i kierunki programu wspierania rozwoju budownictwa mieszkaniowego do 2020 roku" [The main challenges, goals, and approach towards supporting the development of housing by 2020], http://bip.transport.gov.pl/pl/bip/projekty_aktow_prawnych/projekty_ustaw/ustawy_mieszkalnictwo _i_gospodarka_komunalna/bs_mieszk2020/px_18112010gp.pdf.

Ministry of Insfratructure and Development (2014), “Analiza dostępności kredytów mieszkaniowych dla gospodarstw domowych w wieku 25-34 lat" [Analysis of the availability of credit for households aged 25-34]. 
Ministry of Labour and Social Policy (2013), "Strategia Rozwoju Kapitału Ludzkiego 2020" [Human Capital Development Strategy 2020], www.mpips.gov.pl/praca/strategie-i-dokumentyprogramowe/strategia-rozwoju-kapitalu-ludzkiego-srkl---projekt-z-31072012-r/.

Ministry of Transport Construction and Maritime Economy (2013), "Informacja stan mieszkalnictwa i polityka mieszkaniowa" [The Housing Situation in Poland].

Munch, J.R., Rosholm, M., Svarer, M. (2006), Are Homeowners Really More Unemployed? The Economic Journal 116, 991-1013, http://dx.doi.org/10.1111/j.1468-0297.2006.01120.x.

National Development Bank (Bank Gospodarstwa Krajewo) (2015), "Thermo-modernisation fund," https://www.en.bgk.pl/activities/government-target-funds/thermomodernization-fund/ (accessed on May 20, 2015).

Nickell, S., Layard, R. (1999), "Labor market institutions and economic performance," in: Handbook of Labor Economics, pages 3029-3084, http://dx.doi.org/10.1016/S1573-4463(99)30037-7.

OECD (2015a), "Prices: Consumer Prices", Main Economic Indicators (database), http://dx.doi.org/10.1787/data-00047-en.

OECD (2015b), OECD Urban Policy Reviews: Mexico 2015: Transforming Urban Policy and Housing Finance, OECD Publishing, Paris, http://dx.doi.org/10.1787/9789264227293-en.

OECD (2014a), OECD Economic Surveys: Poland 2014, OECD Economic Surveys: Poland, OECD Publishing, Paris, http://dx.doi.org/10.1787/eco_surveys-pol-2014-en.

OECD (2014b), “Better Life Index”, Better Life Index 2014 (database), http://dx.doi.org/http://dx.doi.org/10.1787/data-00704-en.

OECD (2014c), How's Life in Your Region? Measuring Regional and Local Well-Being for Policy Making, OECD Publishing, Paris, http://dx.doi.org/10.1787/9789264217416-en.

OECD (2014d), “Long-Term Unemployment Rate”, (indicator), http://dx.doi.org/10.1787/76471ad5-en.

OECD (2013a), OECD Urban Policy Reviews, Chile 2013, OECD Publishing, Paris, http://dx.doi.org/10.1787/9789264191808-en.

OECD (2013b), "Metropolitan Areas", OECD Regional Statistics (database), http://dx.doi.org/10.1787/data-00531-en.

OECD (2011a), OECD Urban Policy Reviews, Poland 2011, http://dx.doi.org/10.1787/9789264097834-en.

OECD (2011b), Housing and the Economy: Policies for Renovation. Economic Policy Reforms 2011, http://www.oecd.org/newsroom/46917384.pdf.

Office of the Treasury (UK) (2011), "The Green Book: Appraisal and Evaluation in Central Government," www.gov.uk/government/uploads/system/uploads/attachment_data/file/220541/green_book_comple te.pdf.

Oswald, A.J. (1996), A Conjecture on the Explanation for High Unemployment in the Industrialized Nations: Part 1, http://wrap.warwick.ac.uk/1664/. 
Radzimski, A. (2014), Subsidized Mortgage Loans and Housing Affordability in Poland. GeoJournal 79, 467-494, http://dx.doi.org/10.1007/s10708-014-9533-2.

Rekiel, M. (2015), "Thermo-modernization program in Poland," presentation made to the OECD in January 2015.

Salvi del Pero, A., Willem, A., Ferraro, V., Frey, V. (2016), "Policies to promote access to good-quality affordable housing in OECD countries," OECD Social, Employment and Migration Working Papers, Paris, http://dx.doi.org/10.1787/5jm3p5gl4djd-en.

Sánchez, A.C., Andrews, D. (2011), "To move or not to move: What drives residential mobility Rates in the OECD?” OECD Economics Department Working Papers, http://dx.doi.org/10.1787/5kghtc7kzx21-en.

Schumann, A. (2016), "Using Outcome Indicators to Improve Policies: Methods, Design Strategies and Implementation," OECD Regional Development Working Papers, Paris, http://dx.doi.org/10.1787/5jm5cgr8j532-en.

Scottish Government (2014), "Scotland Performs," www.scotland.gov.uk/About/Performance/scotPerforms (accessed on July 1, 2014).

Van der Vlist, A.J., Gorter, C., Nijkamp, P., Rietveld, P. (2002), Residential Mobility and Local HousingMarket Differences. Environment and Planning A 34, 1147-1164.

Weclzwowicz, G. (2002), "From Egalitarian Cities in Theory to Non-egalitarian Cities in Practice: The Changing Social and Spatial Patterns in Polish Cities," in: Marcuse, P., van Kempen, R. (Eds.), Of State and Cities: The Partitioning of Urban Space, Oxford University Press, pages 183-199. 